\title{
Inhibition of Murine Nephritogenic Effector T Cells by a Clone-specific Suppressor Factor
}

\author{
Catherine M. Meyers * and Carolyn J. Kelly** \\ * Renal-Electrolyte Division and ${ }^{\ddagger}$ Immunology Graduate Group, University of Pennsylvania School of Medicine, Philadelphia, \\ Pennsylvania 19104
}

\begin{abstract}
We have used a murine model of organ-specific autoimmunity to characterize therapeutic modalities capable of downregulating the cellular limb of the autoimmune response. Murine interstitial nephritis is an autoimmune disease mediated by tubular antigen-specific $\mathrm{CD8}^{+}$nephritogenic effector $T$ cells which are delayed-type hypersensitivity (DTH) reactive and cytotoxic to renal epithelial cells. Previous studies have demonstrated that disease can be suppressed with experimentally induced populations of $T$ cells $\left(\mathrm{Ts}_{1}\right.$ and $\mathrm{Ts}_{2}$ cells) obtained after injection of tubular antigen-coupled splenocytes into syngeneic mice. As the target of $\mathrm{Ts}_{2}$ is the $\mathrm{CD8}^{+}$effector $\mathrm{T}$ cell, we have evaluated its effects on nephritogenic effector $T$ cell clones isolated from diseased animals. Our studies demonstrate that soluble proteins expressed by $\mathrm{Ts}_{2}$ cells $\left(\mathrm{TsF}_{2}\right)$ specifically abrogate the DTH, cytotoxic, and nephritogenic potential of M52 cells, although $T$ cell receptor and $\mathrm{IL-2}$ receptor expression are unchanged in these unresponsive $\mathbf{M 5 2}$ clones. $\mathrm{TsF}_{2}$-induced inhibition is dependent on new mRNA and protein synthesis. In a cytotoxic clone, M52.26, exposure to $\mathrm{TsF}_{2}$ induces expression of TGF- $\beta 1$ which is, in turn, required for inhibition of cytotoxicity and nephritogenicity. Our studies are consistent with TGF- $\beta 1$ behaving, at least in some $T$ cells, as a nonspecific final effector of clone-specific suppression. ( $J$. Clin. Invest. 1994. 94:2093-2104.) Key words: autoimmunity $-\alpha$ TBM disease $\cdot$ nephritogenic $T$ cells $\cdot$ immune suppression $-T$ cell receptors
\end{abstract}

\section{Introduction}

The development of immunosuppressive modalities targeting injurious cellular immune responses has enormous intrinsic appeal as well as broad potential clinical applications. Several approaches to the development of such modalities have been taken in both autoimmune disease models and experimental

This work was presented in part at the annual meeting of the American Association of Immunologists, New Orleans, Louisiana, June 1990, and at the American Society of Nephrology, Washington, DC, December 1990.

Address correspondence to Carolyn J. Kelly, MD, University of California, San Diego, and VA Medical Center (111-H), 3350 La Jolla Village Drive, San Diego, CA 92161.

Received for publication 1 June 1992 and in revised form 20 April 1994.

J. Clin. Invest.

(C) The American Society for Clinical Investigation, Inc. 0021-9738/94/11/2093/12 \$2.00

Volume 94, November 1994, 2093-2104 transplant rejection. For example, immunosuppressive modalities which target only some $T$ cell phenotypes (1-3), cellsurface determinants preferentially expressed on activated $\mathrm{T}$ cells $(4,5)$, or restricted $T$ cell receptor $(T C R)^{1}$ variable regions (6-9) are efficacious therapies for several experimental autoimmune diseases. An ideal immunosuppressive modality, however, would be antigen or clone specific, targeting only those $\mathrm{T}$ cells involved in the autoimmune, or alloreactive, response. This type of immunosuppression could theoretically be achieved through preferential expansion of specific suppressor $\mathrm{T}$ cells in the host.

Studies performed in several autoimmune disease models induced by immunization have demonstrated that alternate means of antigen presentation can preferentially induce the expansion of $\mathrm{T}$ cells which inhibit disease expression. These techniques include immunization with large amounts of antigen in incomplete Freund's adjuvant $(10,11)$, or intravenous injection of antigen chemically coupled to splenocytes (12-14). The latter method is one initially used to induce hapten-specific suppressor $\mathrm{T}$ cells $(15,16)$. In a murine model of autoimmune kidney disease, anti-tubular basement membrane ( $\alpha$ TBM) disease, intravenous injection of tubular antigen coupled to splenocytes prevents the characteristic inflammatory lesion in the renal interstitium and also improves the histologic lesion in animals with established disease $(17,18)$. The adoptive transfer of specific $T$ cell populations from the recipients of tubular antigencoupled splenocytes inhibits induced $\mathrm{T}$ cell responses to tubular antigen and the histologic expression of disease, strongly supporting the hypothesis that Ts cells are an important component of this immunosuppression (18).

The intravenous injection of tubular antigen-coupled splenocytes into SJL mice $\left(\mathrm{H}-2^{\text {s }}\right)$ induces two phenotypically and functionally distinct populations of Ts cells (18). The $\mathrm{CD}^{+}{ }^{+}$suppressor $\mathrm{T}$ cells (Ts1) inhibit an early stage in the differentiation of the nephritogenic $\mathrm{CD}^{+}$effector $\mathrm{T}$ cells which mediate $\alpha \mathrm{TBM}$ disease, and also induce a population of $\mathrm{CD} 8^{+}$suppressor $\mathrm{T}$ cells $(18-20)$. These $\mathrm{CD}^{+} \mathrm{Ts}$ cells ( $\mathrm{Ts} 2$ ), or soluble proteins secreted by Ts 2 cells $\left(\mathrm{TsF}_{2}\right)$, directly inhibit the function of bulk populations of tubular antigen-specific $\mathrm{CD}^{+}$effector cells through a noncytotoxic mechanism $(18,19)$. While the molecular definition of suppressor factors is still controver-

1. Abbreviations used in this paper: $\alpha \mathrm{TBM}$, anti-tubular basement membrane; SRTA, soluble renal tubular antigen; PPD, purified protein derivative; 3M-1, the nephritogenic moiety in SRTA; CTL, cytotoxic T lymphocyte; MCT, murine proximal tubular epithelial cell line; MTT, 3(4,5dimethylthiazoyl-2-yl)2,5,diphenyltetrazolium bromide; EAE, experimental allergic encephalomyelitis; IL-2R, receptor for IL-2; TCR, T cell receptor for antigen; $\mathrm{V} \beta$, variable region of the TCR $\beta$ chain; $\mathrm{C} \beta$, constant region of the TCR $\beta$ chain; RT/PCR, reverse transcription PCR. 
sial, increasing evidence supports their being closely related to conventional TCR chains $(21-24)$.

We have been interested in developing highly targeted immunotherapy for autoimmune disease and in delineating the cellular and molecular events which define a "suppressed" $T$ cell. We have recently characterized a panel of nephritogenic effector $\mathrm{T}$ cell clones specific for $3 \mathrm{M}-1$, a glycoprotein target antigen of $\alpha$ TBM disease $(25,26)$. These cultured $\mathrm{CD}^{+} \mathrm{T}$ cells, called M52, maintain the functional capacity of nephritogenic effector $T$ cells induced in vivo (26). Class I MHCrestricted M52 cells mediate 3M-1-specific delayed-type hypersensitivity (DTH) and cytotoxic responses, and adoptively transfer interstitial nephritis to naive syngeneic recipients. Analysis of M52 clones has revealed two distinct functional subsets within the M52 cell line. One subset is cytotoxic and not DTH reactive to the target antigen $3 \mathrm{M}-1$. The other subset is DTH reactive but effects less efficient cytotoxicity to $3 \mathrm{M}$-1-expressing tubular epithelial cells (26). Since previous studies suggest that these clones should be the direct target of $\operatorname{TsF}_{2}(18,19)$, we were in a unique position to characterize the state of clonal inactivation resulting from coculture with a suppressor factor. Our studies show that co-culture with $\mathrm{TsF}_{2}$ results in functional inactivation of nephritogenic M52 cells. $\mathrm{TsF}_{2}$ inhibits both cytotoxic and DTH-reactive clones and abrogates the nephritogenic potential of M52 cells in adoptive transfer studies. This inhibitory activity is specific for M52 cells. Metabolic inhibitor studies indicate that $\mathrm{TsF}_{2}$-induced suppression of M52 is dependent on new mRNA and protein synthesis. In the cytotoxic clone, one of these induced mRNA species is TGF- $\beta 1$, which is required for $\mathrm{TsF}_{2}$-induced suppression of cytotoxicity and nephritogenicity.

\section{Methods}

Mice. SJL mice $\left(\mathrm{H}-2^{\mathrm{s}}\right)$ were purchased from the Jackson Laboratory (Bar Harbor, ME).

Antigens and antibodies. Rabbit renal tubular basement membranes were isolated by a differential sieving technique, sonicated, lyophilized, and stored at $-20^{\circ} \mathrm{C}(27)$. Soluble renal tubular antigen (SRTA) was made from these lyophilized membranes by collagenase digestion (28). The nephritogenic moiety in this digestion, the $3 \mathrm{M}-1$ glycoprotein, is purified from SRTA using immunoaffinity chromatography with a mAb (25). P1, a synthetic peptide derived from the cDNA sequence of 3M1 (LLRRRHGDRRSTMSAEVP) was manually synthesized by the simultaneous multiple peptide method of Houghten $(29,30)$. Purified protein derivative (PPD) was obtained from Connaught Laboratories, Ltd. (Willowdale, Ontario, Canada). Neutralizing antibody to TGF$\beta 1$ and normal chicken IgY were purchased from R\&D Systems, Inc. (Minneapolis, MN).

Metabolic inhibitors. Cordycepin ( 3 '-deoxyadenosine), an inhibitor of polyadenylation, and emetine, an inhibitor of protein synthesis, were purchased from Sigma Chemical Co. (St. Louis, MO).

$T$ cell lines (M52 and M61) and clones. $\mathrm{CD}^{+} \mathrm{T}$ cell lines and clones were isolated from immunized mice as previously described (26) and propagated by weekly passage with $20 \mu \mathrm{g} / \mathrm{ml}$ antigen (SRTA, P1, or PPD), $20 \%$ MLA-144 supernatants as a source or IL-2 and other growth factors $(31)$, and $5 \times 10^{6}$ irradiated $(2,500$ rads $)$ syngeneic spleen cells. T cell culture medium consisted of RPMI 1640 (Whittaker M. A. Bioproducts, Inc., Walkersville, MD) supplemented with glutamine, antibiotics (penicillin, streptomycin, gentamicin), $10 \%$ decomplemented FCS, 5\% NCTC-109 (Whittaker M. A. Bioproducts, Inc.), and $2 \times 10^{-5} \mathrm{M}$ 2-ME. Typically, wells became confluent at 4-5 d and were carried every $7 \mathrm{~d}$. All T cells were cultured at $37^{\circ} \mathrm{C}$ in a $5 \% \mathrm{CO}_{2}$ incubator.
Murine kidney cell line. MCT (SJL proximal tubular epithelial) cells were grown at $37^{\circ} \mathrm{C}$ and $5 \% \mathrm{CO}_{2}$ in DME (JRH Biosciences, Lenexa, KS) with $10 \%$ FCS (32). They were used at confluence as target cells for cytotoxicity assays.

Preparation of soluble $\mathrm{Ts}_{2} . \mathrm{CD}^{+}{ }^{+} \mathrm{Ts} 2$ (suppressor-effector) cells were induced by a 5-d co-culture of CD4 ${ }^{+} \mathrm{M} 40$ suppressor-inducer cell supernatants ( $\mathrm{TsF} 1)(20 \% \mathrm{vol} / \mathrm{vol})$, with naive syngeneic splenocytes in T cell medium, SRTA ( $20 \mu \mathrm{g} / \mathrm{ml})$, and MLA-144 supernatants (19, 20 ). Induced splenocytes were then depleted with $\alpha \mathrm{CD} 4 \mathrm{Ab}$ (from GK 1.5 hybridoma [33]) and a mixture of guinea pig and rabbit $\mathrm{C}$. Freezethaw lysates were made of the remaining $\mathrm{CD}^{+} \mathrm{T}$ cells. For some studies, control lysates of induced $\mathrm{CD} 4^{+}$and other $\mathrm{CD}^{+}$cells were prepared similarly. Lysates of $\mathrm{CD}^{+}{ }^{+} \mathrm{T}$ cells induced by TsF1 were prepared after incubation of induced splenocytes with $\alpha \mathrm{CD} 8 \mathrm{Ab}$ (from hybridoma 3.168.8 [34]) and C. The other control lysate was made from $\mathrm{CD}^{+} \mathrm{T}$ cells induced by supernatants of $\mathrm{CD}^{+}{ }^{+} \mathrm{Th}$ cells $(\mathrm{M} 30 \mathrm{~F})$ (35). After a 5-d coculture of M30F with syngeneic splenocytes, $\mathrm{T}$ cell medium, SRTA ( $20 \mu \mathrm{g} / \mathrm{ml})$, and MLA-144 supernatants, CD8 ${ }^{+} \mathrm{T}$ cells were isolated by depletion with $\alpha \mathrm{CD} 4 \mathrm{Ab}$ and $\mathrm{C}$. These lysates were quantitated in cell equivalents, i.e., a lysate derived from $5 \times 10^{6}$ cells was described as $5 \times 10^{6}$ cell equivalents. In some studies, these lysates were added to day 3 cultured T cells $\left(0.5 \times 10^{6}\right.$ cell equivalents added per well of a 24-well plate), and $24 \mathrm{~h}$ later cultures were washed and replated in fresh T cell medium, IL-2, and antigen. Cells were harvested for functional studies or RNA extraction on day 7 of culture.

Local adoptive transfer of DTH. The adoptive transfer of DTH has been described in detail $(26,36)$. In brief, cultured $T$ cells were washed and resuspended at $2.0 \times 10^{7}$ cells $/ \mathrm{ml}$ in $1 \mathrm{mg} / \mathrm{ml}$ of SRTA, PPD, P1, or PBS, and $25 \mu \mathrm{l}$ of each cell preparation were injected into the hind footpad of recipient mice (3-4 mice/group). Footpad swelling as an index of DTH was measured $24 \mathrm{~h}$ later using a spring-loaded engineer's micrometer (model 7308; Mitutoyo/MTI Corp., Paramus, NJ). The magnitude of swelling was expressed as the mean increment between the antigen-challenged footpad and that injected with PBS in inches $\times$ $10^{-3} \pm \mathrm{SEM}$. In some experiments, $\mathrm{T}$ cell subpopulations were selectively depleted by incubation with $\alpha \mathrm{CD} 8$ or $\alpha \mathrm{CD} 4 \mathrm{mAb}$ and C. All footpad measurements were performed by an individual blinded to the experimental protocol.

Adoptive transfer of disease. These adoptive transfers have been previously described $(26,36)$. In brief, naive SJL mice were anesthetized, and $25 \times 10^{6}$ cultured lymphocytes (either M52 or $\mathrm{TsF}_{2}$-pulsed M52 cells) in $\sim 75 \mu$ l of PBS were injected under the kidney capsule with a 30-gauge needle. This volume uniformly lifted the capsule off most of the parenchyma without bleeding. $7 \mathrm{~d}$ later the kidneys were harvested and longitudinally sectioned with preservation of the subcapsular cell layer. After fixation in $10 \%$ buffered formalin, the kidneys were paraffin embedded for staining with hematoxylin and eosin. The kidneys were then examined histologically for the presence of interstitial injury.

Assessment of renal disease. The stained kidney sections were coded for blind reading by two different grading scales. The severity was qualitatively assessed using a scale modified from previous studies (26, 36 ): 0 , no involvement from the subcapsular cell layer; 0.5 , trace pathologic changes of cellular involvement in a focal pattern in the outermost cortical tubular area; 1, superficial, focal peritubular infiltration and tubular atrophy under the transferred cell layer; 2, focal, deeply extending, heavy cellular infiltrates with peritubular damage and tubular atrophy. The sections were also graded by approximating the tubular layer cell depth of the infiltrating front of mononuclear cells. Each layer equalled a tubular diameter and was given one point. The data from both methods were expressed as a mean for each group \pm SEM.

Cytotoxicity assays. This method determines target cell viability (37, 38 ), and has been described in detail previously (26). In brief, the MCT target cells were prepared from confluent cultures by light trypsinization from tissue culture flasks and washed once in serum-containing medium. Cells were then resuspended at $1.0 \times 10^{6} / \mathrm{ml}$ in medium containing $0.5 \mu \mathrm{g} / \mathrm{ml}$ mitomycin C (Sigma Chemical Co.), vigorously vortexed and then $20-\mu \mathrm{l}$ aliquots were dispensed into 96-well flat-bottomed 
Table I. Oligonucleotide Sequences of $5^{\prime}$ and $3^{\prime}$ Primers

\begin{tabular}{|c|c|c|c|}
\hline mRNA species & 5' Primer & 3' Primer & Size of product \\
\hline & $5^{\prime}-3^{\prime}$ & $5^{\prime}-3^{\prime}$ & $b p$ \\
\hline IL-2 (44) & CCACTTCAAGCTCTACAGCGG & CCTTATGTGTTGTAAGCAGGAGG & 463 \\
\hline IL-4 (82) & CCCAGGCCCGACAGCGAGACCC & GCTTTCTCTAACAGTAGGAAACC & 302 \\
\hline IL-6 (83) & CTACCAAACTGGATATAATC & CCGAGTAGATCTCAAAGTGAC & 330 \\
\hline IFN- $\gamma(45)$ & CCCAATAAGAATAATTCTGCCAG & GCTACAATCTGAGTTCAGTCAGC & 308 \\
\hline TNF- $\alpha(84)$ & CCGATGGGTTGTACCTTGTC & AATGACTCCAAAGTAGACC & 307 \\
\hline TGF- $\beta$ (46) & AAGAACTGCTGTGTGCGG & GCATTGCAGGAGCGCACAA & 299 \\
\hline Perforin (47) & GCATGCTTACCACAGGCTCATC & GATAGCCTGTCTCAGAGCCTC & 465 \\
\hline
\end{tabular}

microtiter plates. $180 \mu \mathrm{l}$ of mitomycin C-containing medium $(0.5 \mu \mathrm{g}$ / $\mathrm{ml}$ ) was then added to each well. Adherent target cells were allowed to attach by overnight incubation at $37^{\circ} \mathrm{C}, 5 \% \mathrm{CO}_{2}$. Effector $\mathrm{T}$ cells were harvested from day 5 cultures containing irradiated syngeneic feeders, IL-2, and antigen, and separated by Lympholyte (Cedarlane Labs. Ltd., Hornby, Ontario, Canada) extraction at room temperature. The interface cell layer containing effector $\mathrm{T}$ cells was washed with fresh medium and resuspended at $10 \times 10^{6} \mathrm{cells} / \mathrm{ml}$. Appropriate aliquots were then added to the adherent target cells at effector/target (E/ T) ratios of 5:1-100:1 in triplicate. Plates were incubated for 16-20 $\mathrm{h}$ at $37^{\circ} \mathrm{C}$ and $5 \% \mathrm{CO}_{2}$. Four wells containing target cells received no effector cells as a control for MCT cell viability and four wells containing only medium were used to control for nonspecific dye reduction. After effector cell incubation, $T$ cells were washed from the microtiter wells with warmed $\left(37^{\circ} \mathrm{C}\right)$ medium, and the wells were replated with $180 \mu \mathrm{l}$ of fresh medium. $20 \mu \mathrm{l}$ of MTT dye (Sigma Chemical Co.) solution $(5 \mathrm{mg} / \mathrm{ml}$ in PBS) was added to each well and the plate was incubated for $4 \mathrm{~h}$ at $37^{\circ} \mathrm{C}, 5 \% \mathrm{CO}_{2}$. After this incubation, medium and unreacted dye were aspirated from the wells and $180 \mu \mathrm{l}$ of $0.04 \mathrm{~N} \mathrm{HCl}$ in isopropanol were added to solubilize the formazan dye. In addition, $20 \mu \mathrm{l}$ of 3\% SDS solution was added to solubilize alcohol-induced protein precipitates. The $O D$ at $570 \mathrm{~nm}$ of each well was then determined using a spectrophotometer (Beckman Instrs., Inc., Fullerton, CA). The mean and standard deviation were determined for triplicate samples. The percent cytotoxicity was calculated by the following equation: percent cytotoxicity $=(1-$ OD treated/OD control $) \times 100$.

Cytofluorography. Cytofluorography was performed on M52 clones harvested from day 9 cultures. Cells were washed in PBS, and aliquots of $1 \times 10^{6}$ cells were resuspended in $50 \mu \mathrm{l}$ PBS with $0.1 \%$ BSA (staining buffer). Monoclonal antibodies to the $\alpha / \beta$ TCR (39) and the $\gamma / \delta$ TCR (40) (Pharmingen, La Jolla, CA), and to the $\mathrm{IL}-2$ receptor (IL-2R) (41) were incubated with samples on ice for $20 \mathrm{~min}$, and washed three times with staining buffer. Samples requiring a fluoresceinated secondary antibody (Pharmingen) were then incubated with the appropriate antibody for $20 \mathrm{~min}$ on ice, and washed three times. Stained cells were fixed with $4 \%$ paraformaldehyde in PBS. Fluorescence was recorded on a FACScan cytofluorograph (Becton Dickinson, Mountain View, CA). In each run, 10,000 live gated cells were analyzed.

RNA-extraction. Total cellular RNA was isolated from cultured T cells, after isolation with Lympholyte (Cedarlane Labs. Ltd.), by the single-step method of acid guanidium thiocyanate-phenol-chloroform extraction (42). The extracted RNA was washed with $80 \%$ ethanol, vacuum-dried and resuspended in diethyl pyrocarbonate-treated water. After assessing the purity of the final products by optical density ratios at 260:280 nm, which were typically $>1.7$, the RNA samples were then used for Northern blot analyses or reverse transcribed into cDNA for the polymerase chain reaction.

Northern blot hybridization. Total RNA isolated from $6 \times 10^{6} \mathrm{~T}$ cells was fractionated on a $1.5 \%$ agarose-formaldehyde gel and then transferred to a Zetabind membrane (Cuno Inc., Meriden, CT). Prehybridization and hybridization were conducted at $55^{\circ} \mathrm{C}$ in $0.5 \mathrm{M} \mathrm{Na}_{2} \mathrm{PO}_{4}$ buffer, $7 \%$ SDS, $1 \%$ BSA, and 1 mM EDTA with $50 \mu \mathrm{g} / \mathrm{ml}$ polyadenylic acid (Boehringer Mannheim Biochemicals, Indianapolis, IN) and 50$100 \mu \mathrm{g} / \mathrm{ml}$ sheared salmon sperm DNA. Blots were hybridized to ${ }^{32} \mathrm{P}-$ labeled (random-primed) murine probes (specific activity of $2.0 \times 10^{9}$ $\mathrm{dpm} / \mu \mathrm{g}$ ) for $16 \mathrm{~h}$ at $55^{\circ} \mathrm{C}$. Probes for TCR C $\beta$ (43), IL-2 (44), IFN$\gamma(45)$, TGF- $\beta$ (46), perforin (47), and $\beta$-actin (48) were used in these studies. After hybridization the blots were washed three times with $0.1 \times \mathrm{SSC} / 0.1 \%$ SDS at $65^{\circ} \mathrm{C}$ for $30 \mathrm{~min}$. Autoradiography was performed with intensifying screens at $-70^{\circ} \mathrm{C}$.

$P C R$ amplification of $T$ cell transcripts. Reverse transcription of 10 $\mu \mathrm{g}$ of T cell RNA was performed with $0.25 \mathrm{mM}$ dNTPs (Boehringer Mannheim Biochemicals), $40 \mathrm{U}$ of recombinant RNasin (Promega, Madison, WI), $0.01 \mathrm{M}$ DTT, $0.3 \mu \mathrm{g}$ oligo(dT) $)_{15}, 1 \times$ HRT buffer, and $500 \mathrm{U}$ of M-MLV reverse transcriptase (all from Bethesda Research Laboratories, Gaithersburg, MD). The reaction mixture was incubated at $37^{\circ} \mathrm{C}$ for $60 \mathrm{~min}$, heat inactivated at $95^{\circ} \mathrm{C}$ for $5-10 \mathrm{~min}$, and then quick-chilled on ice. PCR was performed with $1 \times$ PCR buffer II (Perkin-Elmer Corp., Norwalk, CT), final concentration $50 \mathrm{mM} \mathrm{KCl}, 10$ $\mathrm{mM}$ Tris $\mathrm{HCl}$, and $1.0 \mathrm{mM} \mathrm{MgCl}{ }_{2}$ solution (Perkin-Elmer Corp.), 0.20 mM dNTP (Boehringer Mannheim Biochemicals), 0.40 pmol each 3' and 5 ' primer, and $1.25 \mathrm{U}$ of Thermus aquaticus DNA polymerase (Taq polymerase) (Perkin-Elmer Corp.) in a total volume of $100 \mu \mathrm{l}$. The mixture was overlaid with mineral oil and then amplified with a PerkinElmer Corp. thermal cycler. The amplification profile involved 35 cycles of denaturation at $92^{\circ} \mathrm{C}$ for $1 \mathrm{~min}$, primer annealing at $50^{\circ} \mathrm{C}$ for $1 \mathrm{~min}$, and extension at $72^{\circ} \mathrm{C}$ for $2 \mathrm{~min} .10 \mu \mathrm{l}$ of each PCR reaction mixture was electrophoresed in a $2 \%$ agarose gel. Gels were stained with ethidium bromide and photographed.

Oligonucleotides used for amplification. Oligonucleotides were synthesized on a DNA synthesizer (Applied Biosystems, Foster City, CA). The sense $\left(5^{\prime}\right.$ primer) and antisense ( $3^{\prime}$ primer) sequences used for these PCR reactions and the source of the published murine cytokine sequences are as listed in Table I.

Statistical analysis. Differences between experimental groups were determined by Student's $t$ test, where appropriate. Cytotoxicity curves were evaluated using two-way analysis of variance (49).

\section{Results}

$T s F_{2}$ suppresses effector cell DTH reactivity to SRTA. The M52 cell line mediates multiple functions including DTH reactivity, cytotoxicity, and adoptive transfer of interstitial nephritis. We began our studies by first analyzing the effects of $\mathrm{TsF}_{2}$ on the DTH reactivity of the M52 cell line and clones to the target antigen 3M-1. As shown in Table II, M52 cells treated with $\mathrm{TsF}_{2}$ for $24 \mathrm{~h}$ do not display DTH reactivity to tubular antigen by day 7 of culture. Since $\mathrm{TsF}_{2}$ is a cell lysate preparation, we prepared several other control lysates in order to examine the possibility of a nonspecific inhibitory effect of the $\mathrm{TsF}_{2}$ prepara- 
Table II. TsF $F_{2}$ Suppresses M52 DTH Reactivity

to Tubular Antigen

\begin{tabular}{lllc}
\hline \multicolumn{1}{c}{ Donor cells } & $\begin{array}{c}\text { Lysate added } \\
\text { to culture* }\end{array}$ & $\begin{array}{c}\text { Injected } \\
\text { antigen }\end{array}$ & $\begin{array}{c}\text { DTH } \\
\text { response }\end{array}$ \\
\hline M52 & - & SRTA & $19.7 \pm 0.9$ \\
M52 & $\mathrm{TsF}_{2}$ & SRTA & $2.7 \pm 1.2^{\| \prime}$ \\
M52 $(6 \mathrm{mo})^{8}$ & $\mathrm{TsF}_{2}$ & SRTA & $4.0 \pm 1.5^{\prime \prime}$ \\
M52 & $\mathrm{CD}^{+}$lysate & SRTA & $18.7 \pm 0.7$ \\
M52 & $\mathrm{CD}^{+}$lysate & SRTA & $19.0 \pm 0.6$ \\
M61 & $\mathrm{TsF}_{2}$ & PPD & $19.3 \pm 2.8$
\end{tabular}

* $\mathrm{TsF}_{2}$ and the control lysates $\left(\mathrm{CD}^{+}{ }^{+}\right.$lysate and $\mathrm{CD} 8^{+}$lysate) were prepared as described in Methods. The appropriate cell lysate $(0.5$ $\times 10^{6}$ cell equiv/well) was then added to day 3 cultured T cells. $24 \mathrm{~h}$ later the cells were harvested, washed in $\mathrm{T}$ cell media, and replated in fresh media, IL-2, and antigen (SRTA or PPD, $20 \mu \mathrm{g} / \mathrm{ml}$ ). Cells were tested on day 7 of culture. ${ }^{\ddagger}$ Values expressed are the mean of three mice in inches $\times 10^{-3} \pm$ SEM. They represent the incremental difference in footpad swelling, measured $24 \mathrm{~h}$ after challenge, between the footpad that received $0.5 \times 10^{6}$ cells plus antigen (SRTA or PPD, $1 \mathrm{mg} / \mathrm{ml}$ ) and that which received $0.5 \times 10^{6}$ cells and PBS. ${ }^{8}$ After exposure to only a single dose of $\mathrm{TsF}_{2}$, these cells were then carried in culture for many months with weekly passage. " $P<0.001$ compared with M52 cells alone.

tion on M52 cells. These included lysates of CD8 ${ }^{+}$cells induced by the helper cytokine $\mathrm{ThF}(50)$ and lysates of $\mathrm{CD}^{+}{ }^{+} \mathrm{T}$ cells present in the cultures established identically to those used to harvest the $\mathrm{CD}^{+}$lysate $\mathrm{TsF}_{2}$. The data in Table II demonstrate that neither of these control lysates inhibited M52 DTH responses, strongly arguing against a nonspecific effect of the $\mathrm{TsF}_{2}$ lysate preparation. To examine whether $\mathrm{TsF}_{2}$-mediated suppression was specific for M52 cells, we cocultured $\mathrm{TsF}_{2}$ with a PPD-reactive cell line, M61 (26). The bottom line of Table II demonstrates that $\mathrm{TsF}_{2}$ does not inhibit M61 reactivity to PPD.

$\mathrm{TsF}_{2}$ is not cytotoxic to cultured M52 cells as there is no change in M52 viability after exposure to $\mathrm{TsF}_{2}$ (data not shown). Moreover when $\mathrm{TsF}_{2}$-pulsed M52 cells are restimulated with fresh irradiated splenocytes, IL-2, and antigen, they proliferate as well as unpulsed cells, but remain unreactive in DTH assays. $\mathrm{TsF}_{2}$-induced unresponsiveness is long-lived in cultured M52 cells. We have tested them regularly on a monthly basis and find that they are still unresponsive 6 mo after the $\mathrm{TsF}_{2}$ pulse (Table II). This phenomenon is examined in more detail below.

We also tested the effects of $\mathrm{TsF}_{2}$ on M52 clones. As previously stated, the $\mathrm{CD}^{+} \mathrm{M} 52$ cell line is comprised of two functionally distinct phenotypes. One subset is cytotoxic and not DTH reactive to tubular antigen and one is DTH reactive and mediates less efficient cytotoxicity to tubular epithelial cells. We cocultured three DTH-reactive M52 clones with $\mathrm{TsF}_{2}$. As seen in Table III, the DTH responses of these clones, M52.23, M52.28, and M52.34, to the synthetic peptide fragment, P1, of the target antigen $3 \mathrm{M}-1$ (30) is eliminated by pretreatment with $\mathrm{TsF}_{2}$. This functional inhibition of M52 clones, like that of the M52 cell line, also persists for several months in culture.

$T_{s} F_{2}$ inhibits M52.26 mediated cytotoxicity to tubular epithelial cells. Previous studies have demonstrated that M52 medi-
Table III. Ts $F_{2}$ Suppresses DTH Reactivity of M52 Clones to Tubular Antigen

\begin{tabular}{lccc}
\hline & & \multicolumn{2}{c}{ DTH Response* } \\
\cline { 3 - 4 } $\begin{array}{c}\text { Donor } \\
\text { cells }\end{array}$ & $\begin{array}{c}\text { Injected } \\
\text { antigen }\end{array}$ & Control & $\begin{array}{c}\text { TsF }_{2^{-}} \\
\text {pulsed }^{\ddagger}\end{array}$ \\
\hline M52.23 & P1 & $20.3 \pm 0.9$ & $1.0 \pm 0.6^{\S}$ \\
M52.28 & P1 & $18.7 \pm 1.2$ & $2.3 \pm 0.3^{\S}$ \\
M52.34 & P1 & $19.0 \pm 1.2$ & $2.3 \pm 0.3^{\S}$ \\
- & P1 & $1.7 \pm 0.3^{\S}$ & - \\
\hline
\end{tabular}

* See ${ }^{\ddagger}$ of Table II, values are expressed as the mean of three mice in inches $\times 10^{-3} \pm$ SEM. ${ }^{\ddagger}$ See $*$ of Table II. M52 clones were pulsed with $\mathrm{TsF}_{2}$ on day 3 of culture and injected day 7 to asess DTH reactivity. ${ }^{\S} P<0.001$ compared to control, untreated M52 clone.

ates antigen-specific cytotoxicity toward 3M-1-expressing tubular epithelial cells (MCT) in a dose-dependent manner. Both the M52 cell line and M52.26 (a CTL clone) are cytotoxic to MCT between E/T ratios of 5:1 and 50:1, where cytotoxicity approaches $80 \%$. In order to test the effects of $\mathrm{TsF}_{2}$ on this interaction, M52.26 cells were pulsed with $\mathrm{TsF}_{2}$ for $24 \mathrm{~h}$, and then tested for cytotoxicity to MCT cells. As shown in Fig. 1, M52.26 cells pretreated with $\mathrm{TsF}_{2}$ demonstrate a marked decrease in cytotoxicity toward tubular epithelial cells in culture.

M52 cells pulsed with $T s F_{2}$ do not infiltrate the kidney following adoptive transfer. We next examined the ability of $\mathrm{TsF}_{2}$ pulsed M52 cells to elicit an inflammatory interstitial lesion following adoptive transfer. We have previously shown that M52 cells infiltrate the kidney of syngeneic recipients and produce severe interstitial injury after adoptive transfer (26). In the present studies we confirmed the nephritogenicity of M52 cells (Fig. 2, $A$ and $B$, Table IV). The recipients of these cells were sacrificed $7 \mathrm{~d}$ after cell transfer and the kidneys evaluated by light microscopy for both severity of injury and maximum depth of the infiltrating cell front $(26,36)$. Areas of involvement in these kidneys consisted of focal mononuclear infiltrates as well as areas of tubular atrophy and dilatation. In contrast to these lesions, adoptive transfer of $\mathrm{TsF}_{2}$-treated cells did not

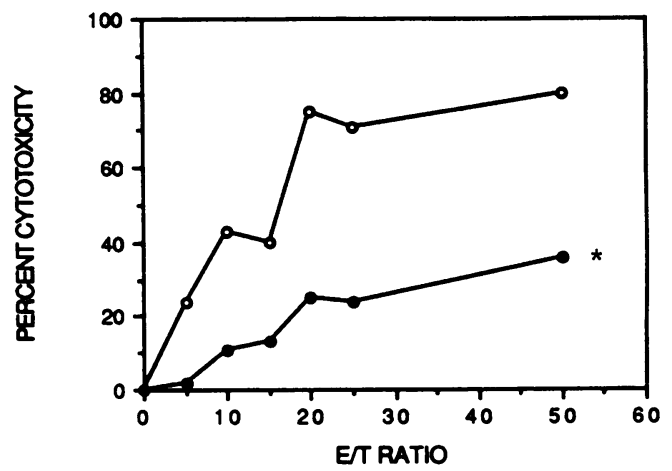

Figure $1 . \mathrm{TsF}_{2}$ inhibits M52.26-mediated cytotoxicity. Adherent target cells (MCT) were incubated with M52.26 cells for $16 \mathrm{~h}$ at $37^{\circ} \mathrm{C}$ and the percent cytotoxicity was determined from the amount of MTT formazan produced, as described in Methods. M52.26/MCT (O), $\mathrm{M} 52.26+\mathrm{TsF}_{2}(\bullet)$. Each data point represents the mean of triplicate samples. The asterisk denotes statistical significance of the curve $(P$ $<0.05$ ) from M52.26/MCT based on two-way analysis of variance. 

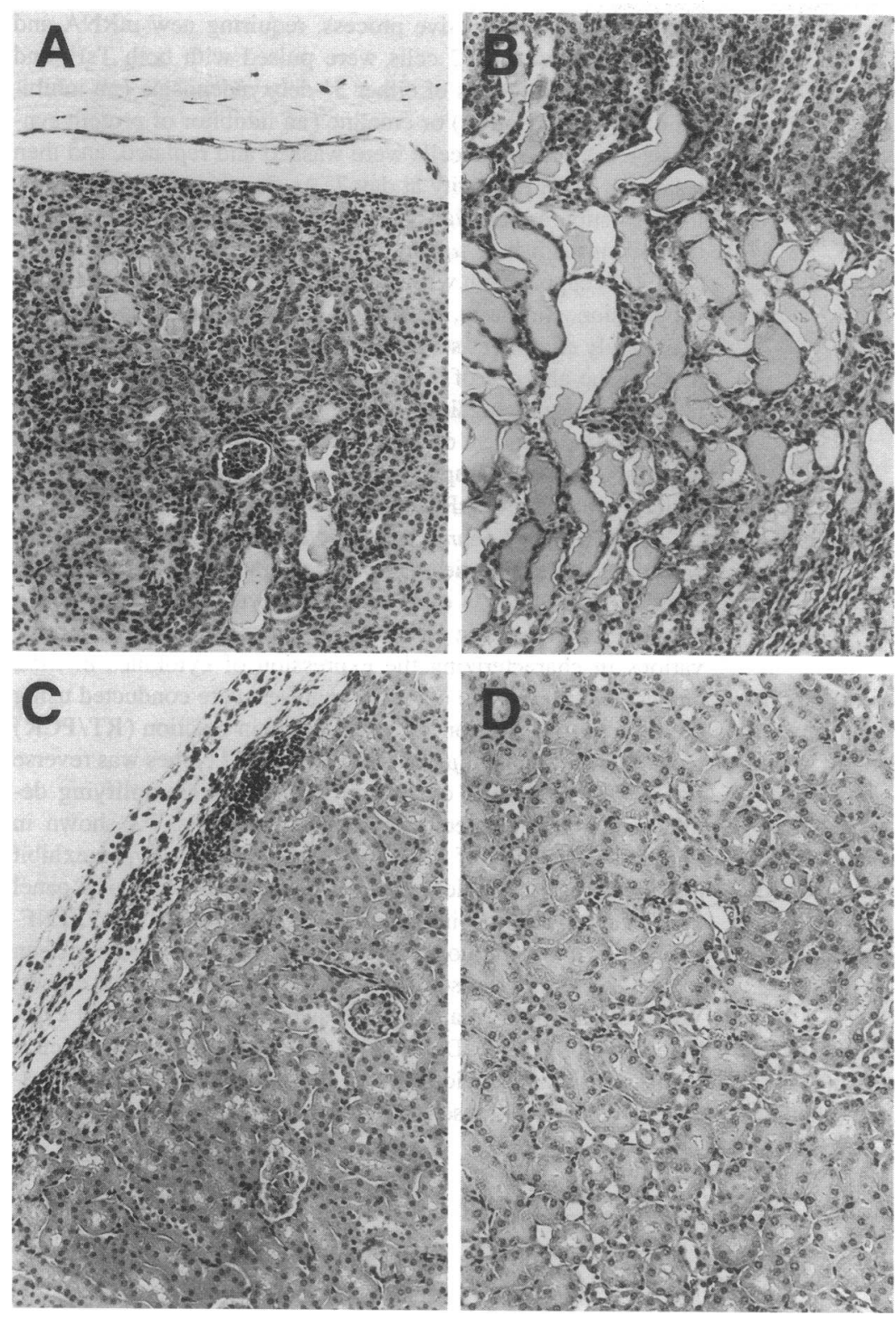

Figure 2. Subcapsular cell transfers. Cultured M52 cells, untreated $(A$ and $B)$ or pulsed with $\mathrm{TsF}_{2}(C$ and $D$ ), were injected under the kidney capsule of naive syngeneic mice. After $7 \mathrm{~d}$ the kidneys were harvested and sectioned for histologic grading. The interstitial lesion typically seen after transfer of M52 cells is seen in both $A$ and $B$. Focal cortical areas of mononuclear cell infiltration are apparent, as well as areas of tubular atrophy and dilatation. M52 cells pretreated with $\mathrm{TsF}_{2}$ do not infiltrate the renal parenchyma, as seen in $C$ and $D$. The interstitial architecture remains normal, and focal subcapsular collections of mononuclear cells are evident $(A-D, \times 200)$.

Table IV. Ts $F_{2}$ Abrogates the Nephritogenicity of M52

\begin{tabular}{lccc}
\hline \multirow{2}{*}{$\begin{array}{c}\text { Cells } \\
\text { injected* }\end{array}$} & Treatment & Histology after subcapsular transfer \\
\cline { 3 - 4 } & & Severity & Maximum depth \\
\hline M52 & - & $1.8 \pm 0.1$ & $19.3 \pm 1.1$ \\
M52 & $\mathrm{TsF}_{2}$ & $0.1 \pm 0.1^{\S}$ & $2.3 \pm 1.3^{\S}$ \\
M61 & - & 0 & 0 \\
\hline
\end{tabular}

* Cultured $\mathrm{T}$ cells were harvested from day 7 cultures. In some groups, cells were pretreated with $\mathrm{TsF}_{2}$ on day 3 of culture. $25 \times 10^{6}$ cells in $75 \mu \mathrm{l}$ of PBS were injected under the kidney capsule of naive SJL mice. $n=4$ for each group. ${ }^{\ddagger} 7 \mathrm{~d}$ after transfer, the kidneys were harvested and sectioned for histologic grading as detailed in Methods. ${ }^{\S} P<0.05$ compared with M52 cells injected. result in any significant interstitial pathology (Fig. 2, $C$ and $D$ ). A formal histologic grading of the two groups is depicted in Table IV, and demonstrates that $\mathrm{TsF}_{2}$ markedly inhibits the ability of M52 cells to cause autoimmune injury. One of four recipients of $\mathrm{TsF}_{2}$-pulsed cells had a small area of mild and superficial inflammation. The other three animals had no detectable renal damage.

$T s F_{2}$-treated effector cells maintain TCR expression. As previously stated, $\mathrm{TsF}_{2}$-pulsed M52 cells and clones restimulated with fresh irradiated splenocytes, IL-2, and antigen, continue to proliferate well but remain unreactive in functional assays. Recent studies in models of induced anergy have suggested that in some cases anergy may be accompanied by diminished cell surface expression of the TCR $(51,52)$. To further evaluate loss of antigen recognition by $\mathrm{TsF}_{2}$-pulsed M52 clones, we examined them for cell-surface TCR expression. Our previous studies have demonstrated that M52 clones express $\alpha \beta$ TCR (26). The Northern hybridization study shown in Fig. 3 was 


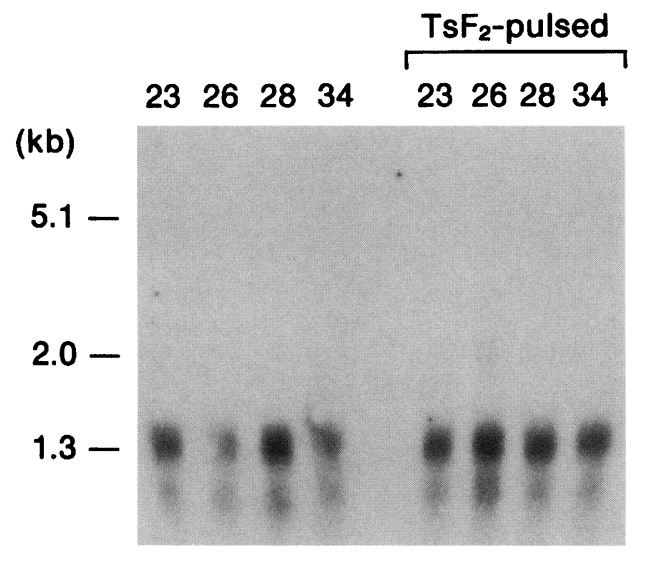

Figure 3. $\mathrm{TsF}_{2}$-pulsed M52 clones maintain TCR expression. $10 \mu \mathrm{g}$ of total RNA derived from M52 clones, either untreated or pulsed with $\mathrm{TsF}_{2}$, was electrophoresed, blotted, and hybridized to a $\mathrm{C} \boldsymbol{\beta}$ probe. The intact TCR- $\beta$ message $(1.3 \mathrm{~kb})$ is present in all clones tested.

conducted with a ${ }^{32} \mathrm{P}$-labeled $\mathrm{C} \beta$ probe, and compares $\beta$ chain mRNA expression in M52 clones before and after exposure to $\mathrm{TsF}_{2}$. The 1.3-kb band apparent in all lanes corresponds to the intact TCR- $\beta$ message, and is unaffected by $\mathrm{TsF}_{2}$ suppression. In addition, cytofluorographic analyses of $\mathrm{TsF}_{2}$-pulsed M52 clones demonstrate persistent cell surface expression of $\alpha \beta$ TCR (Fig. 4), unchanged in intensity from that previously reported for active M52 clones (26). FACS analyses of these clones also demonstrated unchanged IL-2R expression (Fig. 5), consistent with their continued ability to proliferate in response to IL-2.

$\mathrm{Ts}_{2}$ function requires new $m R N A$ and protein synthesis. To better understand the cellular processes which result in $\mathrm{TsF}_{2}$ induced suppression of M52 cells, we next evaluated whether suppression was an active process, requiring new mRNA and protein synthesis. M52 cells were pulsed with both $\mathrm{TsF}_{2}$ and varying concentrations of either $3^{\prime}$-deoxyadenosine (an inhibitor of polyadenylation) or emetine (an inhibitor of protein synthesis). $24 \mathrm{~h}$ later the cells were washed and replated, and then tested for DTH reactivity at day 7 . As shown in Table $\mathrm{V}, \mathrm{TsF}_{2}$ induced suppression was blocked by either inhibitor in a dosedependent manner. $1 \mu \mathrm{g} / \mathrm{ml}$ of 3'-deoxyadenosine does not inhibit $\mathrm{TsF}_{2}$ suppression whereas $50 \mu \mathrm{g} / \mathrm{ml}$ completely eliminates suppression. Similarly, emetine at $10 \mathrm{ng} / \mathrm{ml}$, but not $1 \mathrm{ng} / \mathrm{ml}$, completely eliminates suppression. Inhibitors added to M52 cultures in the absence of $\mathrm{TsF}_{2}$ did not result in augmented DTH responses, arguing against this being a nonspecific effect of the inhibitors independent of $\mathrm{TsF}_{2}$. These studies support the notion that $\mathrm{TsF}_{2}$-mediated suppression is an active cellular process which requires new mRNA and protein synthesis.

$T_{s} F_{2}$-mediated changes in effector cell cytokine gene transcription. Recent studies have demonstrated that some murine $\mathrm{T}$ cell clones $\left(\mathrm{CD} 4^{+}\right)$express distinct cytokine profiles which correlate with function $(53,54)$. We have made similar observations in characterizing the expression of cytokines in M52 clones. Our qualitative cytokine analyses were conducted using the reverse transcription/polymerase chain reaction (RT/PCR) technique in which $10 \mu \mathrm{g}$ of RNA from M52 clones was reverse transcribed, and PCR conducted with primers amplifying defined segments of specific cytokine transcripts. As shown in Fig. 6, M52 clones of different functional phenotypes exhibit distinct cytokine profiles when tested for expression of a panel of relevant cytokines, including IL-2, IL-4, IL-6, IFN- $\gamma$, TNF$\alpha$, TGF- $\beta$, and a cytotoxic mediator, perforin. The pattern seen with M52.34 is representative of most DTH-reactive clones. We could amplify an appropriate size band for all tested cytokines from M52.34 cDNA (Fig. $6 \mathrm{~A}$ ), but even with such a highly sensitive technique we could not demonstrate the presence of a perforin transcript. The cytotoxic clone, M52.26, con-

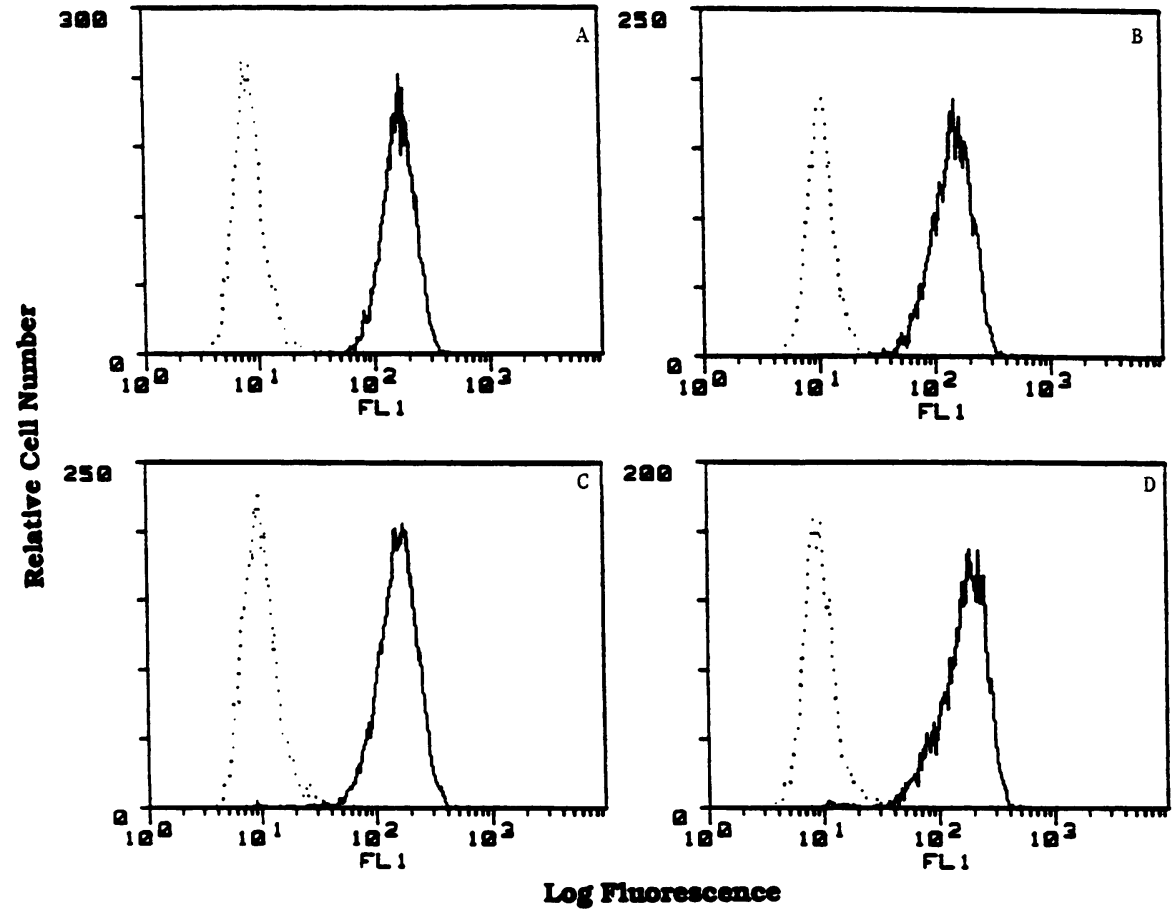

Figure 4. Cell surface expression of TCR on $\mathrm{TsF}_{2}$-treated M52 clones. Day 9 cultured M52 clones, which had been pulsed with $\mathrm{TsF}_{2}$ on Day 3, $(A) \mathrm{M} 52.23,(B) \mathrm{M} 52.26$, (C) M52.28, (D) M52.34, were incubated with FITC-hamster anti-mouse TCR Abs. $\alpha \beta$ TCR Ab (----), and $\gamma \delta$ TCR Ab $(---)$. 

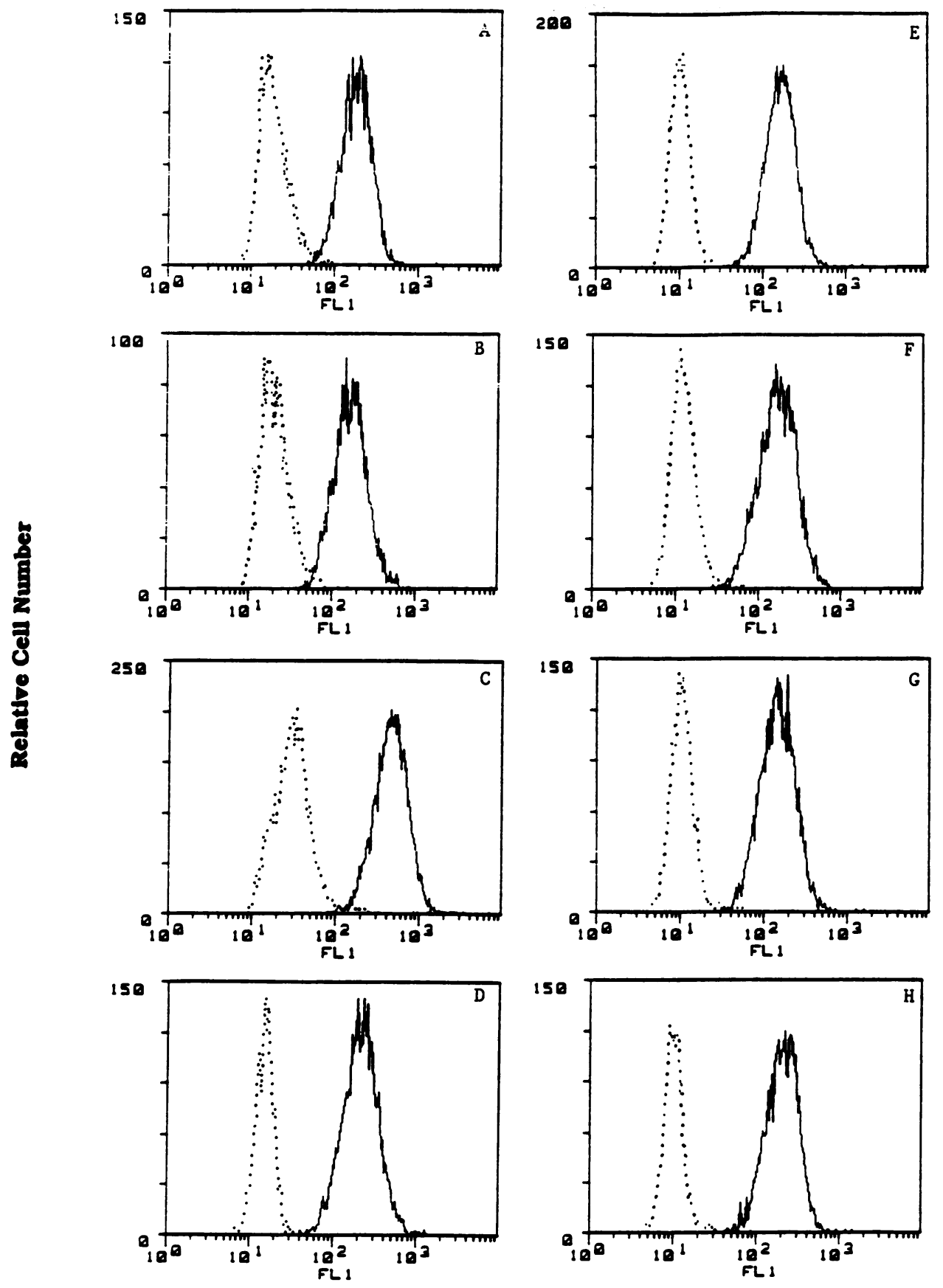

Figure 5. Cell surface expression of Il-2R on M52 clones. Day 9 M52 clones were incubated with rat antimouse II-2R Abs, $(A) \mathrm{M} 52.23,(B)$ M52.26, (C) M52.28, (D) M52.34. Clones were also analyzed after $\mathrm{TsF}_{2}$ treatment $(E) \mathrm{M}^{2} 2.23,(F)$ M52.26, $(G) \mathrm{M} 52.28,(H) \mathrm{M} 52.34$. $\alpha$-IL-2R Ab (-----) and $\alpha$-rat IgG $(---)$.

sistently displayed a different pattern of cytokine expression, as shown in Fig. $6 \mathrm{~B}$. M52.26 expresses a perforin transcript and all tested cytokines, except for IL- 2 and TGF- $\beta$. Since these patterns are highly reproducible, in our hands, for a given $\mathrm{T}$ cell clone, we used this as a screening technique to determine whether the $\mathrm{TsF}_{2}$-induced change in $\mathrm{M} 52$ function was also associated with a change in cytokine gene expression. The RNA used for these analyses was harvested from $\mathrm{TsF}_{2}$-pulsed clones at a time when the cells were functionally inactive. Fig. 6 also reveals the cytokine pattern of both a cytotoxic (M52.26) and a DTH-reactive (M52.34) clone after pretreatment with $\mathrm{TsF}_{2}$, and exhibits changes from baseline studies of functional M52 clones. In the cytotoxic clone, IL-2 message remains undetectable, but TGF- $\beta$ expression is induced, and perforin and IFN$\gamma$ expression is lost. In the DTH-reactive clone, IL-2 expression is no longer apparent but the expression of other cytokines is maintained, although the intensity of amplified PCR products for several cytokines was consistently diminished. To further investigate quantitative changes in cytokine expression, we performed Northern hybridization studies. The results of these studies, shown in Fig. 7, confirm the major cytokine changes observed in M52 clones following $\mathrm{TsF}_{2}$ treatment, and also reveal 
Table V. Ts $F_{2}$ Function Requires New $m R N A$ and Protein Synthesis

\begin{tabular}{|c|c|c|}
\hline $\begin{array}{l}\text { Pretreatment of } \\
\text { M52 cells* }\end{array}$ & $\begin{array}{c}\text { Inhibitors added to M52 } \\
\text { cells }\end{array}$ & $\begin{array}{l}\text { DTH } \\
\text { response to } \\
\text { SRTA }^{8}\end{array}$ \\
\hline- & - & $18.3 \pm 1.9$ \\
\hline $\mathrm{TsF}_{2}$ & - & $5.0 \pm 0.6^{\| \prime}$ \\
\hline $\mathrm{TsF}_{2}$ & 3-DA $(1 \mu \mathrm{g} / \mathrm{ml})$ & $4.0 \pm 1.0^{\|}$ \\
\hline $\mathrm{TsF}_{2}$ & 3-DA $(10 \mu \mathrm{g} / \mathrm{ml})$ & $9.7 \pm 3.4$ \\
\hline $\mathrm{TsF}_{2}$ & 3-DA $(50 \mu \mathrm{g} / \mathrm{ml})$ & $21.7 \pm 3.0$ \\
\hline- & $3-\mathrm{DA}(50 \mu \mathrm{g} / \mathrm{ml})$ & $19.7 \pm 2.2$ \\
\hline $\mathrm{TsF}_{2}$ & Emetine $(1 \mathrm{ng} / \mathrm{ml})$ & $4.7 \pm 0.3^{\|}$ \\
\hline \multirow[t]{2}{*}{$\mathrm{TsF}_{2}$} & Emetine $(10 \mathrm{ng} / \mathrm{ml})$ & $15.0 \pm 2.1$ \\
\hline & Emetine (100 ng/ & \\
\hline \multirow[t]{2}{*}{$\mathrm{TsF}_{2}$} & $\mathrm{ml})$ & $16.3 \pm 0.9$ \\
\hline & Emetine (100 ng/ & \\
\hline - & $\mathrm{ml})$ & $17.7 \pm 0.7$ \\
\hline
\end{tabular}

* $\mathrm{TsF}_{2}$ was added to day $3 \mathrm{M} 52$ cultures $\left(0.5 \times 10^{6}\right.$ cell equiv/well). $24 \mathrm{~h}$ later the cells were harvested, washed, and replated in fresh medium, IL-2, and SRTA $(1 \mathrm{mg} / \mathrm{ml})$. Cells were again harvested on Day 7 and injected into naive recipient SJL mice. ${ }^{\ddagger}$ Varying concentrations of either 3-deoxyadenosine (3-DA), an inhibitor of polyadenylation, or emetine, an inhibitor of protein synthesis, were added to day 3 M52 cultures with $\mathrm{TsF}_{2}$, and then washed as described above. ${ }^{8}$ See Table II, values are expressed as the mean of three mice in inches $\times 10^{-3}$ \pm SEM. $" P<0.001$ compared with M52 cells injected alone.

a reduction of IFN- $\gamma$ expression in $\mathrm{TsF}_{2}$-treated DTH-reactive clones. Fig. $7 B$ shows the induction of TGF- $\beta$ and the loss of perforin and IFN- $\gamma$ in the cytotoxic clone, M52.26. The lack of IL-2 expression in the DTH-reactive clones is also apparent.

$T_{s} F_{2}$ inactivation of M52.26-mediated cytotoxicity and nephritogenicity is reversed by neutralizing antisera to TGF-

\section{A}

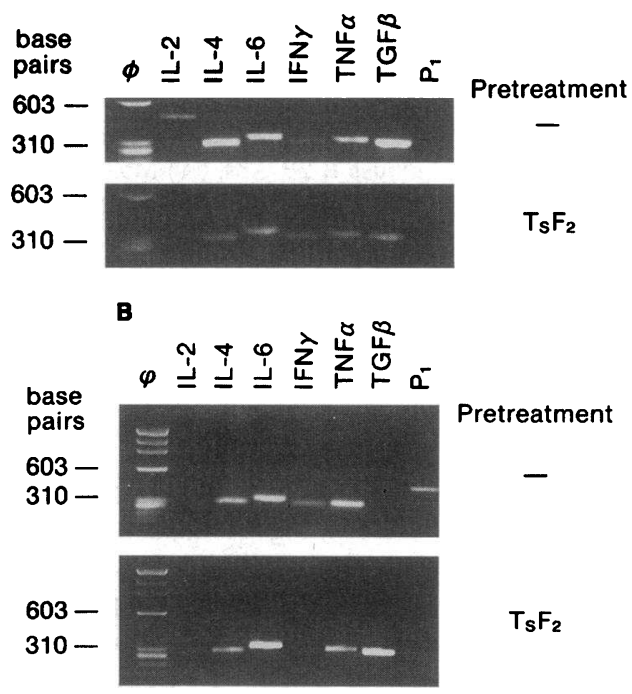

Figure 6. Analysis of cytokine and perforin (or murine P1) production of untreated and $\mathrm{TsF}_{2}$-pulsed M52 clones by RT/PCR of total RNA. Amplified fragments of anticipated size were detected by ethidium bromide staining of $1.8 \%$ agarose gels. $(A)$ Representative pattern of DTHreactive clones, M52.34. ( $B$ ) Cytokine profile of M52.26, a CTL clone.
A
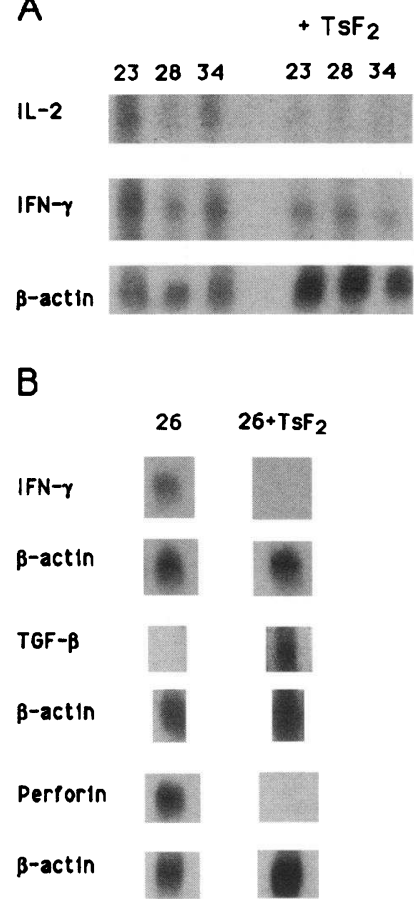

Figure 7. Northern hybridization studies of $\mathrm{TsF}_{2}$-induced changes in M52 clonal cytokine expression. $10 \mu \mathrm{g}$ of total RNA derived from untreated and $\mathrm{TsF}_{2}$-pulsed M52 clones was electrophoresed, blotted onto a nylon membrane, and hybridized with cytokine probes. $(A)$ The DTH-reactive clones, M52.23, M52.28, and M52.34 were evaluated for their expression of IL-2 and IFN- $\gamma$, and $(B)$ M52.26, a CTL, was examined for its expression of IFN- $\gamma$, TGF- $\beta 1$, and perforin. The lower panels reveal the hybridization of the blots to a $\beta$-actin probe and demonstrate the relative amount of RNA loaded in each lane. $\beta 1$. Our screening for cytokine transcripts by RT-PCR revealed only one (TGF- $\beta 1$ ) which was induced in a $\mathrm{TsF}_{2}$-treated clone (M52.26). Given the studies supporting a requirement for new mRNA and protein synthesis to see suppression, we next examined whether neutralizing antisera to TGF- $\beta 1$ would interfere with $\mathrm{TsF}_{2}$-mediated suppression of M52.26. Fig. 8 demonstrates that neutralizing antisera to TGF- $\beta 1(10 \mu \mathrm{g} / \mathrm{ml})$ completely

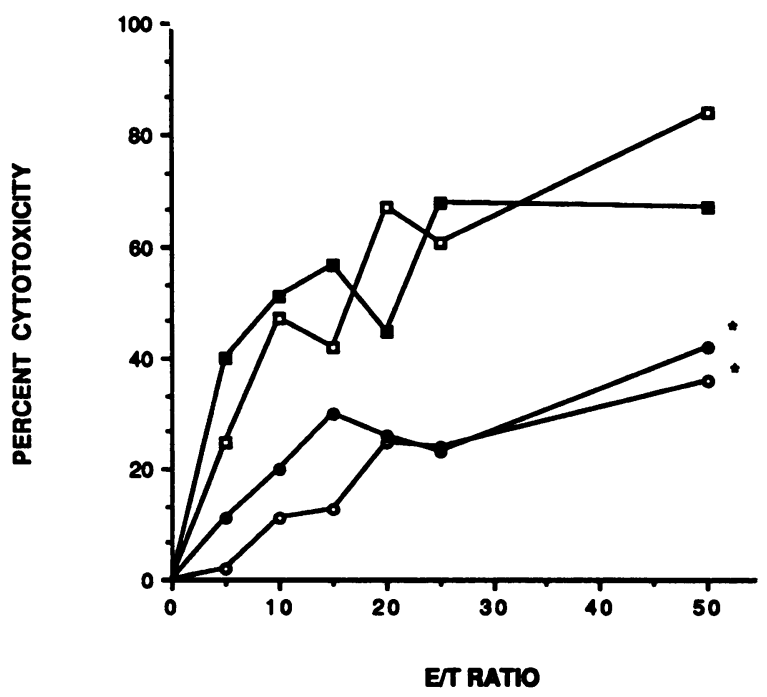

Figure 8. Neutralizing $\alpha \mathrm{TGF}-\beta$ Ab inhibits $\mathrm{TsF}_{2}$-mediated suppression of CTL activity. The cytotoxic potential of clone M52.26 toward tubular epithelial cells was evaluated, using the MTT assay, with untreated M52.26 ( $\square$ ), and M52.26 pretreated with $\mathrm{TsF}_{2}(0), \mathrm{TsF}_{2}+\alpha$ TGF- $\beta$ $\mathrm{Ab}(10 \mu \mathrm{g} / \mathrm{ml})(\square)$, or $\mathrm{TsF}_{2}+\operatorname{IgY}(10 \mu \mathrm{g} / \mathrm{ml})(\bullet)$. Each data point represents the mean of triplicate samples. The asterisk denotes statistical significance of the curve $(P<0.05)$ from M52.26 based on two-way analysis of variance. 
Table VI. Formal Analysis of Interstitial Lesions After Adoptive Transfer

\begin{tabular}{cccc}
\hline & & \multicolumn{2}{c}{$\begin{array}{c}\text { Histology after subcapsular } \\
\text { transfer }\end{array}$} \\
\cline { 3 - 4 } $\begin{array}{c}\text { Cells } \\
\text { injected* }\end{array}$ & Pretreatment & Severity & $\begin{array}{c}\text { Maximum } \\
\text { depth }\end{array}$ \\
\hline M52.26 & - & $1.9 \pm 0.1$ & $33.2 \pm 2.8$ \\
M52.26 & $\mathrm{TsF}_{2}$ & $0^{8}$ & $0^{8}$ \\
M52.26 & $\mathrm{TsF}_{2}+\alpha \mathrm{TGF}-\beta_{1} \mathrm{Ab}$ & $1.0 \pm 0.1$ & $16.3 \pm 1.9$ \\
& $(10 \mu \mathrm{g} / \mathrm{ml})$ & & \\
M52.26 & $\mathrm{TsF}_{2}+$ Control Ab & $0^{8}$ & $0^{8}$ \\
& $(10 \mu \mathrm{g} / \mathrm{ml})$ & &
\end{tabular}

* Cultured $\mathrm{T}$ cells clones were harvested from day 7 cultures. In some groups, cells were pretreated with $\mathrm{TsF}_{2}, \alpha \mathrm{TGF}-\beta \mathrm{Ab}$, or an irrelevant $\mathrm{Ab}$ (chicken IgY) on day 3 of culture. $25 \times 10^{6}$ cells in $75 \mu \mathrm{l}$ of PBS were injected under the kidney capsule of naive SJL mice. $n=3-5$ for each group. ${ }^{\ddagger} 7 \mathrm{~d}$ after transfer, the kidneys were harvested and sectioned for histologic grading as detailed in Methods. ${ }^{B} P<0.001$ compared with M52.26 cells injected.

abrogates the $\mathrm{TsF}_{2}$-mediated suppression of M52.26 cytotoxicity to tubular epithelial cells. Normal chicken IgY had no effect. This concentration of neutralizing $\alpha$ TGF- $\beta 1$ blocks $95-100 \%$ of the effect of $0.25 \mathrm{ng} / \mathrm{ml}$ of TGF- $\beta 1$ on IL-4-dependent ${ }^{3}[\mathrm{H}]-$ thymidine incorporation by HT-2 cells ( R \& D specifications, neutralizing dose ${ }_{50}$ is $2-3 \mu \mathrm{g} / \mathrm{ml}$ ). Neutralizing $\alpha$ TGF- $\beta 1$ has no augmenting effect on M52.26-mediated cytotoxicity to MCT cells in the absence of $\mathrm{TsF}_{2}$ (data not shown), consistent with our previous findings (Figs. 6 and 7) that TGF- $\beta 1$ is not expressed by M52.26 cells in the absence of $\mathrm{TsF}_{2}$.

The importance of TGF- $\beta 1$ in $\mathrm{TsF}_{2}$-mediated suppression of M52.26 is further underscored by the analysis of adoptive transfer studies displayed in Table VI. M52.26 cells treated with $\mathrm{TsF}_{2}$ and the $\alpha \mathrm{TGF}-\beta 1$ antibody from day 3 of culture were nephritogenic compared with those treated with $\mathrm{TsF}_{2}$ with or without the control IgY. While the lesions seen in the group receiving both $\mathrm{TsF}_{2}$ and $\alpha \mathrm{TGF}-\beta 1$ antibody had the same histologic features (mononuclear cells and tubular dilatation) as those seen with untreated M52.26 cells, the numerical severity and depth indices were significantly less. This difference may reflect a difference in the duration of action of $\mathrm{TsF}_{2}$ versus $\alpha$ TGF- $\beta 1$ antibody, since the $\mathrm{TsF}_{2}$ functional effect persists (Table II) while the neutralizing capability of the antibody is likely lost when the cells are harvested, washed, and resuspended in PBS for adoptive transfer.

\section{Discussion}

The concept that $\mathrm{T}$ cells can be functionally inhibited in an antigen- or clone-specific manner by the product of another $\mathrm{T}$ cell is certainly not a novel one. A number of investigators have described this phenomenon and have distinguished the effects of antigen-specific suppressor factors (TsFs) from nonspecific inhibitory cytokines ( such as TGF- $\beta$ ) as well as from cytotoxicity or the absence of help (55-57). Research in the area of antigen-specific suppression became highly controversial in the 1980's, when Ts hybridomas were shown not to express conventional TCR (58) and the molecular definition of TsFs remained unclear. In the past several years though, investigators working in several distinct antigenic systems have unequivocally demonstrated the presence of conventional $\alpha \beta$ TCR on Ts hybridomas and clones $(23,56,59)$. Recent studies strongly support a longstanding hypothesis that these suppressor factors are comprised, at least in part, of conventional TCR polypeptides $(21,22,24$, 59). These findings have rekindled an interest in exploring the potential of antigen-specific immunosuppression for the therapy of autoimmune disease and transplant rejection.

Evidence that regulatory $\mathrm{T}$ cells can have a profound impact on both histologic abnormalities and functional organ impairment exists in several models of autoimmunity, including $\alpha$ TBM disease $(11,17,18,20,60)$, interstitial nephritis in $k d k d$ mice $(61)$, insulin-dependent diabetes in NOD mice $(62,63)$, thyroiditis $(10,64)$, and experimental allergic encephalomyelitis $(\mathrm{EAE})(12,14,65)$. How Ts cells function to impair autoimmune $\mathrm{T}$ and/or $\mathrm{B}$ cell clones is less clear. Previous work in murine $\alpha$ TBM disease demonstrated that bulk populations of the $\mathrm{CD}^{+}$effector $\mathrm{T}$ cells could be functionally inhibited in a noncytotoxic manner by $\mathrm{CD}^{+}$splenocytes (or cell lysates) from recipients of Ag-coupled splenocytes (18). In this study we used four previously characterized nephritogenic $T$ cell clones (26) to more closely examine the mechanism of their inactivation.

We first confirmed that the inhibitory effect of the cell lysate, $\mathrm{TsF}_{2}$, is specific for the M52 clones and also not a nonspecific effect of a lysate preparation. $\mathrm{TsF}_{2}$ functionally inhibits both cytotoxic clones and DTH-reactive clones and, perhaps most importantly, the ability of these $T$ cells to elicit an inflammatory response in the interstitium of the kidney after adoptive transfer. Previous studies in this model demonstrated that the $\mathrm{CD}^{+} \mathrm{Ts}$ cells and $\mathrm{TsF}_{2}$ are anti-idiotypic and that this might provide a structural basis for their interaction with idiotypeexpressing $\mathrm{CD}^{+}{ }^{+}$effector $\mathrm{T}$ cells (18). The recent observations from the rat model of EAE that TCR $\mathrm{V} \beta 8$ region peptides can induce or augment anti- $\mathrm{V} \beta 8 \mathrm{~T}$ cells and antibodies provides a structural basis for such an idiotypic-antiidiotypic interaction as well as another example of how this interaction can be immunosuppressive in the setting of organ-specific autoimmunity (7, $8)$. In EAE the encephalitogenic $T$ cells preferentially utilize the $V \beta 8.2$ gene $(6,66)$ and therefore induced anti-V $\beta 8$ immune responses can effectively target the majority of encephalitogenic clones. The target of $\mathrm{TsF}_{2}$ may be intact M52 TCR or processed TCR peptides. We are presently investigating the $\mathrm{V}$ regions used by these clones.

Although we were initially impressed that exposure to $\mathrm{TsF}_{2}$ induced an indefinite state of unresponsiveness, this finding is consistent with the complete inhibition of nephritogenic $T$ cell expression and disease activity documented in previous studies $(18-20)$. The fact that the cell line and clones continued to grow well immediately after exposure to $\mathrm{TsF}_{2}$ and when repassaged, led us to examine whether we could identify some alteration in cell-surface receptors or cytokine expression which might explain their inability to function. While we cannot rule out an alteration in a cell-surface molecule, TCR expression and IL-2R expression are unchanged from their baseline level of expression in functional clones. There are, however, characteristic and reproducible alterations in cytokine expression in M52 clones after exposure to $\mathrm{TsF}_{2}$.

Many investigators have described modifications of RT/ PCR techniques which allow for quite precise quantitation of transcript copy number (67). Our use of RT-PCR was as a 
screening technique to demonstrate major alterations in specified cytokine transcripts. As a screen, we have found the general pattern and relative intensity of amplified cytokine PCR products is highly reproducible both with the same starting template and from one experiment to the next. It is a useful technique to analyze $\mathrm{T}$ cell clones which have not been transformed, since it minimizes the number of cells required.

We were intrigued to find that the loss of function induced by $\mathrm{TsF}_{2}$ is dependent upon new RNA and protein synthesis. These inhibitor studies suggest that at some point, suppression is an active process. An analogy may be made to in vitro models of $\mathrm{T}$ cell unresponsiveness induced by chemical pretreatment of the antigen-presenting cell or exposure of $\mathrm{T}$ cells to antigen complexed to purified MHC in planar membranes (68-70). The induction phase of unresponsiveness in these systems is also an active process requiring new protein synthesis, as it can be blocked by cycloheximide (70). It is interesting that a critical event in these anergic $\mathrm{CD} 4{ }^{+}$clones appears to be the marked reduction in IL-2 production after $\mathrm{T}$ cell activation although IL-2R expression is maintained, as are normal levels of TCR expression $(68,69)$. We have made similar observations in our studies of $\mathrm{TsF}_{2}$ inhibition of M52 clones. The distinction, however, is that in these other models of $\mathrm{T}$ cell unresponsiveness, $\mathrm{CD}^{+}{ }^{+}$cells recover function after restimulation with antigen and IL-2. The functional inhibition we observe with M52 is not readily reversible.

The cytokine alterations we have observed in $\mathrm{TsF}_{2}$-pulsed clones persist as well. The observation that these alterations are closely correlated temporally with loss of function suggests that they are relevant changes. It is reasonable to hypothesize that a clone which can no longer express IL-2 and proliferate in situ may not be able to elicit an inflammatory interstitial lesion. Lower levels of IFN- $\gamma$ expression may additionally impair a local DTH reaction in the interstitium of the kidney. In the purely cytotoxic clone, $\mathrm{M} 52.26, \mathrm{TsF}_{2}$ exposure results in loss of perforin gene expression and a marked decrease in its ability to kill tubular epithelial cells. This observation is intriguing to us for several reasons. The mechanisms of cytotoxicity by CTL clones continues to be an active area of research and there is still controversy regarding the physiologic significance of perforin-expressing CTL (71-73). M52.26, our most efficient CTL (26), is the only M52 clone analyzed thus far which expresses perforin. Our findings that a maneuver that shuts off perforin expression is associated with significant inhibition of cytotoxicity, is strong suggestive evidence that perforin is an important mediator of cytotoxicity for M52.26. Since the other M52 clones are also cytolytic to MCT cells (26) (albeit less efficiently), our studies support the existence of perforin-independent modes of CTL action as well by autoimmune effector $\mathrm{T}$ cells.

The consistent finding that TGF- $\beta 1$ expression is induced in M52.26 following exposure to $\mathrm{TsF}_{2}$ was particularly intriguing, in view of multiple studies supporting a role for TGF- $\beta$ in suppression of $T$ cell functions (74-78). The absence of TGF- $\beta$ expression by M52.26 when active additionally suggested that TGF- $\beta$ may be one of the induced mRNA species required for suppression ( Table $\mathrm{V}$ ). The studies performed with neutralizing antisera to TGF- $\beta 1$ unequivocally demonstrate that TGF- $\beta 1$ is required for $\mathrm{TsF}_{2}$-mediated suppression of M52.26. Ongoing studies in our laboratory suggest that exogenously added TGF- $\beta 1$ is also sufficient as a single signal to inhibit M52.26 mediated cytotoxicity and nephritogenicity (78a). Stud- ies in EAE have also demonstrated suppression-related changes in effector T cell cytokine expression (79). In this model, CD4 ${ }^{+}$ Ts inhibit IFN- $\gamma$, but not IL-2 expression in effector T cells of EAE, and recent investigations have implicated TGF- $\beta$ in these Ts-mediated effects $(80,81)$. It is quite plausible that once $\mathrm{TsF}_{2}$ has induced TGF- $\beta$ expression in a T cell such as M52.26, the clone in effect inactivates itself. Such a regulatory mechanism in vivo could locally downregulate $\mathrm{T}$ cell-mediated responses and disease activity. This explanation, however, does not apply to clones such as M52.34, which expresses TGF- $\beta 1$ following activation and are not inactivated by exogenous TGF$\beta 1$. The mechanism by which $\mathrm{TsF}_{2}$ inactivates such clones is under active investigation.

\section{Acknowledgments}

The authors are grateful to Hank Pletcher for assistance with the cytofluorography.

This work was supported in part by National Institutes of Health grants DK-42155, DK-08343, and DK-45346. C. M. Meyers is the recipient of a Clinician Scientist Award (91-4090) from the American Heart Association. C. J. Kelly was a Lucille P. Markey Scholar (86019 ) and this work was also supported by the Lucille P. Markey Charitable Trust.

\section{References}

1. Brostoff, S. W., and D. W. Mason. 1984. Experimental allergic encephalomyelitis: successful treatment in vivo with a monoclonal antibody that recognizes T helper cells. J. Immunol. 133:1938-1942.

2. Sriram, S., and C. A. Roberts. 1986. Treatment of established chronic relapsing experimental allergic encephalomyelitis with anti-L3T4 antibodies. $J$. Immunol. 136:4464-4469.

3. Waldor, M. K., S. Sriram, R. Hardy, L. A. Herzenberg, L. Lanier, M. Lim, and L. Steinman. 1985. Reversal of experimental allergic encephalomyelitis with monoclonal antibody to a $\mathrm{T}$ cell subset marker. Science (Wash. DC). 227:415417.

4. Kelley, V. E., G. N. Gaulton, M. Hattori, H. Ikkegami, G. Eisenbarth, and T. B. Strom. 1988. Anti-interleukin 2 receptor antibody suppreses murine diabetic insulitis and lupus nephritis. J. Immunol. 140:59-61.

5. Schluesener, H. J., R. A. Sobel, and H. L. Weiner. 1988. Demyelinating experimental allergic encephalomyelitis (EAE) in the rat: treatment with a monoclonal antibody against activated T cells. J. Neuroimmunol. 18:341-351.

6. Acha-Orbea, H., D. J. Mitchell, L. Timmermann, D. C. Wraith, G. S. Tausch, M. K. Waldorr, S. S. Zamvil, H. O. McDevitt, and L. Steinman. 1988. Limited heterogeneity of $\mathrm{T}$ cell receptors from lymphocytes mediating autoimmune encephalomyelitis allows specific immune intervention. Cell. 54:263-273.

7. Howell, M. D., S. T. Winters, T. Olee, H. C. Powell, D. J. Carlo, and S. W. Brostoff. 1989. Vaccination against experimental allergic encephalomyelitis with T cell receptor peptides. Science (Wash. DC). 246:688-670.

8. Vandenbark, A. A., G. Hashim, and H. Offner. 1989. Immunization with a synthetic $\mathrm{T}$ cell receptor $\mathrm{V}$ region peptide protects against experimental autoimmune encephalomyelitis. Nature (Lond.). 341:541-544.

9. Zaller, D. M., G. Osman, O. Kanagawa, and L. Hood. 1990. Prevention and treatment of murine experimental allergic encephalomyelitis with $\mathrm{T}$ cell receptor $\mathrm{V} \beta$-specific antibodies. J. Exp. Med. 171:1943-1955.

10. Braley-Mullen, H., G. C. Sharp, M. Kyriakos, N. Hayes, C. Dunn, P. Jepsen, and R. D. Sanders. 1978. Suppression of experimental autoimmune thyroiditis in the guinea pig by pretreatment with thyroglobulin in incomplete Freund's adjuvant. Cell. Immunol. 39:289-292.

11. Kelly, C. J., M. D. Clayman, and E. G. Neilson. 1986. Immunoregulation in experimental interstitial nephritis: Immunization with renal tubular antigen in incomplete Freund's adjuvant induces major histocompatibility complex-restricted, $\mathrm{OX8}^{+}$suppressor $\mathrm{T}$ cells which are antigen-specific and inhibit the expression of disease. J. Immunol. 136:903-907.

12. Kennedy, M. K., M. C. DalCanto, J. L. Trotter, and S. D. Miller. 1988. Specific immune regulation of chronic-relapsing experimental allergic encephalomyelitis in mice. J. Immunol. 141:2986-2993.

13. Schoen, R. T., M. I. Greene, and D. E. Trentham. 1982. Antigen-specific suppression of type II collagen-induced arthritis by collagen-coupled spleen cells. J. Immunol. 128:717-719.

14. Sriram, S., G. Schwartz, and L. Steinman. 1983. Administration of myelin 
basic protein-coupled spleen cells prevents experimental allergic encephalomyelitis. Cell. Immunol. 75:378-382.

15. Dorf, M. E., and B. Benacerraf. 1984. Suppressor cells and immunoregulation. Annu. Rev. Immunol. 2:127-158.

16. Greene, M. I., M. J. Nelles, M. S. Sy, and A. Nisonoff. 1982. Regulation of immunity to the azobenzenearsonate hapten. Adv. Immunol. 32:253-300.

17. Mann, R., and E. G. Neilson. 1986. Murine interstitial nephritis V. The auto-induction of antigen-specific Lyt- ${ }^{+}$suppressor $\mathrm{T}$ cells diminishes the expression of interstitial nephritis in mice with antitubular basement membrane disease. J. Immunol. 1986:908-912.

18. Neilson, E. G., E. McCafferty, R. Mann, L. Michaud, and M. D. Clayman. 1985. Tubular antigen-derivatized cells induce a disease-protective, antigen-specific, and idiotype-specific suppressor T cell network restricted by I-J and Igh-V in mice with experimental interstitial nephritis. J. Exp. Med. 162:215-230.

19. Hines, W. H., R. A. Mann, and E. G. Neilson. 1988. Murine interstitial nephritis. VII. Characterization of Igh-V restriction determinants in the development of anti-idiotypic immunity using blocking antibodies. J. Autoimmun. 1:143157.

20. Neilson, E. G., C. J. Kelly, M. D. Clayman, W. H. Hines, T. Haverty, M. J. Sun, and N. Blanchard. 1987. Murine interstitial nephritis VII. Suppression of renal injury after treatment with soluble suppressor factor TsF1. J. Immunol. 139:1518-1524.

21. Green, D. R., R. Bissonnette, H. Zheng, T. Onda, F. Echeverri, R. J. Mogil, J. K. Steele, M. Voralia, and A. Fotedar. 1991. Immunoregulatory activity of the T-cell receptor $\alpha$ chain demonstrated by retroviral gene transfer. Proc. Natl. Acad. Sci. USA. 88:8475-8479.

22. Kuchroo, V. K., M. C. Byrne, Y. Atsumi, E. Greenfield, J. B. Connolly, M. J. Whitters, R. M. O'Hara, M. Collins, and M. E. Dorf. 1991. T-cell receptor $\alpha$ chain plays a critical role in antigen-specific suppressor cell function. Proc. Natl. Acad. Sci. USA. 88:8700-8704.

23. Takata, M., P. K. Maiti, R. T. Kubo, Y. Chen, V. Holford-Stevens, E. S. Rector, and A. H. Sehon. 1990. Cloned suppressor T cells derived from mice tolerized with conjugates of antigen and monomethoxypolyethylene glycol. Relationship between monoclonal $\mathrm{T}$ suppressor factor and the $\mathrm{T}$ cell receptor. $J$. Immunol. 145:2846-2853.

24. Zheng, H., B. M. Sahai, P. Kilgannon, R. Fotedar, and D. R. Green. 1989. Specific inhibition of cell-surface $T$ cell receptor expression by antisense oligodeoxynucleotides and its effect on the production of an antigen-specific regulatory T cell factor. Proc. Natl. Acad. Sci. USA. 86:3758-3762.

25. Clayman, M., A. Martinez-Hernandez, L. Michaud, R. Alper, R. Mann, N. A. Kefalides, and E. G. Neilson. 1985. Isolation and characterization of the nephritogenic antigen producing anti-tubular basement membrane disease. J. Exp. Med. 161:290-305.

26. Meyers, C. M., and C. J. Kelly. 1991. Effector mechanisms in organspecific autoimmunity I. Characterization of a CD8 ${ }^{+} \mathrm{T}$ cell line that mediates murine interstitial nephritis. J. Clin. Invest. 88:408-416.

27. Neilson, E. G. and S. M. Phillips. 1982. Murine interstitial nephritis I Analysis of disease susceptibility and its relationship to pleiomorphic gene products defining both immune response genes and a restrictive requirement for cytotoxic T cells at H-2K. J. Exp. Med. 125:1075-1085.

28. Neilson, E. G., E. McCafferty, S. M. Phillips, M. D. Clayman, and C. J. Kelly. 1984. Antiidiotypic immunity to interstitial nephritis II. Rats developing anti-tubular basement membrane disease fail to make an antiidiotypic regulatory response: the modulatory role of an $\mathrm{RT} 7.1^{+}, \mathrm{OX}^{-}$suppressor $\mathrm{T}$ cell mechanism. J. Exp. Med. 159:1009-1026.

29. Houghten, R. A. 1985. General method for the rapid solid-phase synthesis of large numbers of peptides: specificity of antigen-antibody interaction at the level of individual amino acids. Proc. Natl. Acad. Sci. USA. 82:5131-5135.

30. Neilson, E. G., M. J. Sun, C. J. Kelly, W. H. Hines, T. P. Haverty, M. D. Clayman, and N. E. Cooke. 1991. Molecular characterization of a major nephritogenic domain in the autoantigen of anti-tubular basement membrane disease. Proc. Natl. Acad. Sci. USA. 88:2006-2010.

31. Rabin, H., R. F. Hopkins, F. W. Ruscetti, R. H. Neubauer, R. L. Brown, and T. G. Kawakami. 1981. Spontaneous release of a factor with properties of $T$ cell growth factor from a continuous line of primate tumor T cells. J. Immunol. 127:1852-1856.

32. Haverty, T. P., C. J. Kelly, W. H. Hines, P. S. Amenta, M. Watanabe, R. A. Harper, N. A. Kefalides, and E. G. Neilson. 1988. Characterization of a renal tubular epithelial cell line which secretes the autologous target antigen of autoimmune experimental interstitial nephritis. J. Cell. Biol. 107:1359-1368.

33. Wilde, D. B., P. Marrack, J. Kappler, D. Dialynas, and F. Fitch. 1983. Evidence implicating L3T4 in class II MHC antigen reactivity: monoclonal antibody GK 1.5 (anti-L3T4) blocks class II MHC antigen-specific proliferation, release of lymphokines, and binding by cloned murine helper $\mathrm{T}$ lymphocyte lines. J. Immunol. 131:2178-2183.

34. Sarmiento, M., A. L. Glasebrook, and F. W. Fitch. 1980. IgG or IgM monoclonal antibodies reactive with different determinants on the molecular complex bearing Lyt-2 antigen block T cell-mediated cytolysis in the absence of complement. J. Immunol. 125:2665-2672.

35. Mann, R., C. J. Kelly, W. H. Hines, M. D. Clayman, N. Blanchard, M. J.
Sun, and E. G. Neilson. 1987. Effector T cell differentiation in experimental interstitial nephritis I. The development and modulation of effector lymphocyte maturation by ${\mathrm{I}-\mathrm{J}^{+}}^{+}$regulatory T cells. J. Immunol. 136:4200-4208.

36. Neilson, E. G., E. McCafferty, R. Mann, L. Michaud, and M. Clayman. 1985. Murine interstitial nephritis III. The selection of phenotypic (Lyt and L3T4) and idiotypic (RE-Id) T cell preferences by genes in Igh-1 and H-2K characterize the cell-mediated potential for disease expression: susceptible mice provide a unique effector $\mathrm{T}$ cell repertoire in response to tubular antigen. J. Immunol. 134:2375-2382.

37. Green, L. M., J. L. Reade, and C. F. Ware. 1984. Rapid colormetric assay for cell viability: application to the quantitation of cytotoxic and growth inhibitory lymphokines. J. Immunol. Methods. 70:257-268.

38. Mosmann, T. 1983. Rapid colorimetric assay for cellular growth and survival: application to proliferation and cytotoxicity assays. J. Immunol. Meth ods. 65:55-63.

39. Kubo, R. T., W. Born, J. W. Kappler, P. Marrack, and M. Pigeon. 1989. Characterization of a monoclonal antibody which detects all murine alpha beta $\mathrm{T}$ cell receptors. J. Immunol. 142:2736-2742.

40. Goodman, T., and L. Lefrancois. 1989. Intraepithelial lymphocytes. Anatomical site, not $\mathrm{T}$ cell receptor form, dictates phenotype and function. J. Exp. Med. 170:1569-1581.

41. Zubler, R. H., J. W. Lowenthal, F. Erard, N. Hashimoto, R. Devos, and H. R. MacDonald. 1984. Activated B cells express receptors for, and proliferate in response to, pure IL-2. J. Exp. Med. 160:1170-1183.

42. Chomczynski, P. and N. Sacchi. 1987. Single-step method of RNA isolation by acid guanidinium thiocyanate-phenol-chloroform extraction. Anal. Biochem. 162:156-159.

43. Malissen, M., K. Minard, S. Mjolsness, M. Kronenberg, J. Goverman, T. Hunkapiller, M. Prystowsky, Y. Yoshikai, F. Fitch, and T. Mak. 1984. Mouse T cell antigen receptor: structure and organization of constant and joining gene segments encoding the beta polypeptide. Cell. 37:1101-1112.

44. Yokota, T., N. Arai, F. Lee, D. Rennick, T. Mosmann, and K.-I. Arai 1985. Use of a cDNA expression vector for isolation of mouse interleukin 2 cDNA clones: Expression of T-cell growth-factor activity after transfection of monkey cells. Proc. Natl. Acad. Sci. USA. 82:68-72.

45. Gray, P. W., and D. V. Goeddel. 1983. Cloning and expression of murine immune interferon cDNA. Proc. Natl. Acad. Sci. USA. 80:5842-5846.

46. Derynck, R., J. A. Jarrett, E. Y. Chen, and D. V. Goeddel. 1986. The murine transforming growth factor- $\beta$ precursor. J. Biol. Chem. 261:4377-4379.

47. Lowrey, D. M., T. Aebischer, K. Olsen, M. Lichtenheld, F. Rupp, H. Hengartner, and E. R. Podack. 1989. Cloning, analysis, and expression of murine perforin 1 cDNA, a component of cytolytic $T$ cell granules with homology to complement component C9. Proc. Natl. Acad. Sci. USA. 86:247-251.

48. Alonso, S., A. Minty, Y. Bourlet, and M. Buckingham. 1986. Comparison of three actin-coding sequences in the mouse; evolutionary relationships between the actin genes of warm-blooded vertebrates. J. Mol. Evol. 23:11-22.

49. Armitage, P., and G. Berry. 1987. Statistical Methods in Medical Research. Blackwell Scientific Publications, Inc., Cambridge, MA. 559 pp.

50. Hines, W. H., R. A. Mann, C. J. Kelly, and E. G. Neilson. 1990. Murine interstitial nephritis IX. Induction of the nephritogenic effector T cell repertoire with an antigen-specific T cell cytokine. J. Immunol. 144:75-83.

51. Rocha, B., and H. vonBoehmer. 1991. Peripheral selection of the T cell repertoire. Science (Wash. DC). 251:1225-1228.

52. Schonnch, G., U. Kalinke, F. Momburg, M. Malissen, A. Schmitt-Verhulst, B. Malissen, G. Hammerling, and B. Arnold. 1991. Downregulation of T cell receptors on self-reactive $\mathrm{T}$ cells as a novel mechanism for extrathymic tolerance induction. Cell. 65:293-304.

53. Mosmann, T. R., H. Cherwinski, M. W. Bond, M. A. Giedlin, and R. L. Coffman. 1986. Two types of murine helper T cell clone. I. Definition according to profiles of lymphokine activities and secreted proteins. J. Immunol. 136:2348 2357.

54. Street, N. E., J. H. Schumacher, T. A. T. Fong, H. Bass, D. F. Fiorentino J. A. Leverah, and T. R. Mosmann. 1990. Heterogeneity of mouse helper T cells Evidence from bulk cultures and limiting dilution cloning for precursors of $\mathrm{Th}$ and Th2 cells. J. Immunol. 144:1629-1639.

55. Devens, B. H., A. W. Koontz, J. A. Kapp, C. W. Pierce, and D. R. Webb. 1991. Involvement of two distinct regulatory $\mathrm{T}$ cell populations in the antigenspecific suppression of cytolytic T cell generation. J. Immunol. 146:1394-1401

56. Hisatsune, T., A. Enomoto, K. Nishijima, Y. Minai, Y. Asano, T. Tada and S. Kaminogawa. 1990. CD8 ${ }^{+}$suppressor T cell clone capable of inhibiting the antigen- and anti-T cell receptor-induced proliferation of Th clones without cytolytic activity. J. Immunol. 145:2421-2426.

57. Koide, J., and E. G. Engleman. 1990. Differences in surface phenotype and mechanism of action between alloantigen-specific $\mathrm{CD}^{+}$cytotoxic and suppressor T cell clones. J. Immunol. 144:32-40.

58. Hedrick, S. M., R. N. Germain, M. J. Bevan, M. E. Dorf, I. Engel, P. Fink, N. Gascoigne, E. Heber-Katz, J. Kapp, Y. Kaufmann, J. Kaye, F. Melchers, C. Pierce, R. H. Schwartz, C. Sorensen, M. Taniguchi, and M. M. Davis. 1985 Rearrangement and transcription of a $\mathrm{T}$ cell receptor beta chain gene in different T cell subsets. Proc. Natl. Acad. Sci. USA. 82:531-538. 
59. Collins, M., V. K. Kuchroo, M. J. Whitters, R. M. O'Hara, K. Kelleher, R. T. Kubo, and M. E. Dorf. 1990. Expression of functional $\alpha \beta$ T cell receptor gene rearrangements in suppressor $\mathrm{T}$ cell hybridomas correlates with antigen binding, but not with suppressor cell function. J. Immunol. 145:2809-2819.

60. Kelly, C. J., W. K. Silvers, and E. G. Neilson. 1985. Tolerance to parenchymal self. Regulatory role of major histocompatibility complex-restricted, OX8 suppressor $\mathrm{T}$ cells specific for autologous renal tubular antigen in experimental interstitial nephritis. J. Exp. Med. 162:1892-1903

61. Kelly, C. J., and E. G. Neilson. 1987. Contrasuppression in autoimmunity. Abnormal contrasuppression promotes the expression of nephritogenic effector $\mathrm{T}$ cells and histologic interstitial nephritis in kdkd mice. J. Exp. Med. 165:107123.

62. Boitard, C., A. Bendelac, M. F. Richard, C. Carnaud, and J. F. Bach. 1988. Prevention of diabetes in nonobese diabetic mice by anti-I-A monoclonal antibodies: Transfer of protection by splenic T cells. Proc. Natl. Acad. Sci. USA 85:9719-9723

63. Pankewycz, O., T. B. Strom, and V. E. Rubin-Kelley. 1991. Islet-infiltrating $\mathrm{T}$ cell clones from non-obese diabetic mice that promote or prevent accelerated onset of diabetes. Eur. J. Immunol. 21:873-879.

64. Braley-Mullen, H., J. G. Tompson, G. C. Sharp, and M. Hyriakos. 1980 Suppression of experimental autoimmune thyroiditis in guinea pigs by pretreatment with thyroglobulin-coupled spleen cells. Cell. Immunol. 51:408-413.

65. Lider, O., L. M. B. Santos, C. S. Y. Lee, P. J. Higgins, and H. L. Weiner. 1989. Suppression of experimental allergic encephalomyelitis by ora administration of myelin basic protein. II. Suppression of disease and in vitro immune responses is mediated by antigen-specific $\mathrm{CD}^{+} \mathrm{T}$ lymphocytes. $J$. Immunol. 142:748-732.

66. Burns, F. R., X. Li, N. Shen, H. Offner, Y. K. Chou, A. Vandenbark, and $\mathrm{E}$. Heber-Katz. 1989. Both rat and mouse $\mathrm{T}$ cell receptors specific for the encephalitogenic determinant of myelin basic protein use similar $\mathrm{V} \alpha$ and $\mathrm{V} \beta$ chain genes even though the major histocompatibility complex and enchephalitogenic determinants being recognized are different. J. Exp. Med. 169:27-39.

67. Wang, A. M., M. V. Doyle, and D. F. Mark. 1989. Quantitation of mRNA by the polymerase chain reaction. Proc. Natl. Acad. Sci. USA. 86:9717-9721.

68. Jenkins, M. K., D. M. Pardoll, J. Mizuguchi, T. M. Chused, and R. H. Schwartz. 1987. Molecular events in the induction of a nonresponsive state in interleukin 2-producing helper T-lymphocyte clones. Proc. Natl. Acad. Sci. USA 84:5409-5413.

69. Jenkins, M. K., and R. H. Schwartz. 1987. Antigen presentation by chemically modified splenocytes induces antigen-specific $\mathrm{T}$ cell unresponsiveness in vitro and in vivo. J. Exp. Med. 165:302-319.

70. Quill, H., and R. H. Schwartz. 1987. Stimulation of normal inducer T cell clones with antigen presented by purified Ia molecules in planar lipid membranes: Specific induction of a long-lived state of proliferative nonresponsiveness. $J$. Immunol. 138:3704-3712.

71. Ostergaard, H. L., and W. R. Clark. 1989. Evidence for multiple lytic pathways used by cytotoxic T lymphocytes. J. Immunol. 143:2120-2126.

72. Podack, E. R. and A. Kupfer. 1991. T-cell effector functions: Mechanisms for delivery of cytotoxicity and help. Annu. Rev. Cell Biol. 7:479-504.
73. Young, L. H. Y., L. B. Peterson, L. S. Wicker, P. M. Peresechini, and J. D.-E. Young. 1989. In vivo expression of perforin by $\mathrm{CD}^{+}$lymphocytes in autoimmune disease. Studies on spontaneous and adoptively transferred diabetes in nonobese diabetic mice. $J$. Immunol. 143:3994-3999.

74. Kehrl, J. H., L. M. Wakefield, A. B. Roberts, S. B. Jakowiew, M. AlverezMon, R. Derynck, M. B. Sporn, and A. S. Fauchi. 1986. Production of transforming growth factor $\beta$ by human T lymphocytes and its potential role in the regulation of T cell growth. J. Exp. Med. 163:1037-1053

75. Racke, M. K., S. Dhib-Jalbut, B. Cannella, P. S. Albert, C. S. Raine, and D. E. McFarlin. 1991. Prevention and treatment of chronic relapsing experimental allergic encephalomyelitis by transforming growth factor- $\beta$. J. Immunol. 146:3012-3017.

76. Ruegemer, J. J., S. N. Ho, J. A. Augustine, J. W. Schlager, M. P. Bell, D. J. McDean, and R. T. Abraham. 1990. Regulatory effects of transforming growth factor- $\beta$ on IL-2-and IL-4-dependent T cell-cycle progression. J. Immunol. 144:1767-1776.

77. Tada, T., S. Ohzeki, K. Utsumi, H. Takiuchi, M. Muramatsu, X. Li, J. Shimizu, H. Fujiwara, and T. Hamaoka. 1991. Transforming growth factor- $\beta$ induced inhibition of $\mathrm{T}$ cell function. Susceptibility difference in $\mathrm{T}$ cells of various phenotypes and functions and its relevance to immunosuppression in the tumorbearing state. J. Immunol. 146:1077-1082

78. Wahl, S., D. A. Hunt, H. L. Wong, S. Dougherty, N. McCartney-Francis, L. Wahl, L. Ellingsworth, J. A. Schmidt, G. Hall, A. B. Roberts, and M. B. Sporn. 1988. Transforming growth factor- $\beta$ is a potent immunosuppressive agent that inhibits IL-1-dependent lymphocyte proliferation. J. Immunol. 140:3026-3032.

78a. Meyers, C. M., and C. J. Kelly. 1994. Immunoregulatory effects of transforming growth factor $\beta 1$ in autoimmunity. Kidney Int. In press.

79. Karpus, W. J., and R. H. Swanborg. 1989. CD4 ${ }^{+}$suppressor cells differentially affect the production of IFN- $\gamma$ by effector cells of experimental autoimmune encephalomyelitis. J. Immunol. 143:3492-3497.

80. Karpus, W. J., and R. H. Swanborg. 1991. CD4 ${ }^{+}$suppressor cells inhibit the function of effector cells of experimental autoimmune encephalomyelitis through a mechanism involving transforming growth factor- $\beta$. J. Immunol. 146:1163-1168.

81. Miller, A., A. Roberts, M. Sporn, O. Lider, and H. L. Weiner. 1991. In vivo administration of anti-TGF- $\beta$ antibody increases the severity and duration of experimental allergic encephalomyelitis (EAE) and reverses suppression of EAE by oral tolerance to myelin basic protein. Ann. Neurol. 30:303a (Abstr.).

82. Noma, Y., P. Sideras, T. Naito, S. Bergstedt-Lindquist, C. Azuma, E. Severrinson, T. Tanabe, T. Kinashi, F. Matsuda, Y. Yaoita, and T. Honjo, 1986. Cloning of cDNA encoding the murine IgG1 induction factor by a novel strategy using SP6 promoter. Nature (Lond.). 319:640-642.

83. VanSnick, J., S. Cayphas, J. P. Szikora, J. C. Renauld, E. Roost, T. Boon, and R. J. Simpson. 1988. cDNA cloning of murine interleukin-HP1: homology with human interleukin 6. Eur. J. Immunol. 18:193-197.

84. Fransen, L., R. Muller, A. Marmenout, J. Tavernier, J. Van der Heyden, E. Kawashima, A. Chollet, R. Tizard, H. Van Heuverswyn, A. Van Vliet, M. R. Ruysschaert, and W. Fiers. 1985. Molecular cloning of mouse tumour necrosis factor cDNA and its eukaryotic expression. Nucleic Acids Res. 13:4417-4429. 